\title{
Effect of rigor state, when processed, on rainbow trout (Oncorhynchus mykiss) fillet quality
}

Oluwatoyin E. Adebisi

West Virginia University

Follow this and additional works at: https://researchrepository.wvu.edu/etd

\section{Recommended Citation}

Adebisi, Oluwatoyin E., "Effect of rigor state, when processed, on rainbow trout (Oncorhynchus mykiss) fillet quality" (2012). Graduate Theses, Dissertations, and Problem Reports. 3501.

https://researchrepository.wvu.edu/etd/3501

This Thesis is protected by copyright and/or related rights. It has been brought to you by the The Research Repository @ WVU with permission from the rights-holder(s). You are free to use this Thesis in any way that is permitted by the copyright and related rights legislation that applies to your use. For other uses you must obtain permission from the rights-holder(s) directly, unless additional rights are indicated by a Creative Commons license in the record and/ or on the work itself. This Thesis has been accepted for inclusion in WVU Graduate Theses, Dissertations, and Problem Reports collection by an authorized administrator of The Research Repository @ WVU. For more information, please contact researchrepository@mail.wvu.edu. 


\title{
EFFECT OF RIGOR STATE, WHEN PROCESSED, ON RAINBOW \\ TROUT (Oncorhynchus mykiss) FILLET QUALITY
}

\author{
Oluwatoyin E. Adebisi \\ Thesis submitted to the \\ Davis College of Agriculture, Natural Resources, and Design \\ at West Virginia University \\ In partial fulfillment of the requirements \\ For the degree of \\ Master of Science \\ in \\ Animal and Nutritional Sciences \\ P. Brett Kenney, PhD., Chair \\ Jacek Jaczynski, PhD \\ Hillar Klandorf, PhD
}

Division of Animal Nutrition and Sciences

Morgantown, West Virginia

2012

Key words: rainbow trout, processing time, $\mathrm{pH}$, texture, ATP breakdown products. 


\title{
EFFECT OF RIGOR STATE, WHEN PROCESSED, ON RAINBOW TROUT (Oncorhynchus mykiss) FILLET QUALITY
}

\author{
Oluwatoyin E. Adebisi
}

\begin{abstract}
A study was conducted to investigate the effect of rigor development, at time of processing, on weight and length changes, proximate analysis, $\mathrm{pH}, \mathrm{K}$-value, color, and texture of rainbow trout (Oncorhynchus mykiss) fillets. Texture of cooked fillets was characterized using two instrumental methods: Allo-kramer and Variable blade. Forty-five rainbow trout were harvested and immediately slaughtered using percussive stunning they were stored, following evisceration, at $4^{\circ} \mathrm{C}$ on ice. Fish were processed at 0,24 , and $48 \mathrm{~h}$ postharvest, and fillets were vacuumed packaged and stored for 2 days at $4^{\circ} \mathrm{C}$. These storage treatments were applauded in the context of a randomized complete block design. Condition factor, whole body weight, head-on gutted (HOG) weight, length, percent butterfly fillet, HOG weight, and separable muscle were not affected $(\mathrm{P}>0.05)$ by processing time. After cooking, dimensional changes were not different as a function of processing time. At $48 \mathrm{~h}$ postharvest, fillets were wider and longer ( $\mathrm{P}>0.05$ ), in value than the other groups. The 0 -h, postharvest fillets were thicker $(\mathrm{P} \leq 0.05)$ than those filleted at 24 and 48h, indicative of dimensional changes associated with muscle contraction in the absence of skeletal restraint.

At $0 \mathrm{~h}$, fillet $\mathrm{pH}$ was $(\mathrm{P} \leq 0.05)$ higher than at 24 or $48 \mathrm{~h}$; it is likely that all tissue glycogen had not been metabolized to lactic acid. Fillets moisture content and cook loss were $(\mathrm{P}>0.05)$ lower at $0 \mathrm{~h}$ than at 24 and $48 \mathrm{~h}$ fillets, and higher cooked moisture was observed for fillets processed at $0 \mathrm{~h}$. A higher fat content in raw $(6.44 \pm 0.40)$ fillets and a lower fat content in cooked fillets (4.38 \pm 0.35$)$ were measured for $0 \mathrm{~h}$ fillets compared to 24 and $48 \mathrm{~h}$ product. Ash and protein content was $(\mathrm{P} \leq$ 0.05 ) higher at $0 \mathrm{~h}$ postharvest than at 24 and $48 \mathrm{~h}$. A significant rapid decline in rigor angle from $0-24$ $\mathrm{h}$ was observed, which is indicative of rigor resolution. Fillets $\mathrm{L}^{*}$ value increased $(\mathrm{P} \leq 0.05)$ as processing time, postharvest, increased; it was highest at $48 \mathrm{~h}$ processing. Meanwhile, $0 \mathrm{~h}$ fillets exhibited a $(\mathrm{P} \leq 0.05)$ higher redness and yellowness value. The $0 \mathrm{~h}$ fillets had shorter sarcomere length than fillets produced at 24 or $48 \mathrm{~h}$ postharvest. ATP (Adenosine triphosphate) catabolizes and shear force were measured at $48 \mathrm{~h}$ postharvest for all processing treatments. Texture of trout fillet were affected ( $\mathrm{P} \leq 0.05$ ) by time of processing, which might be due to the activity of myofibrillar proteolysis within the fillets' muscle. During rigor development, ATP concentration decreased as fillets went into rigor. Adenosine triphosphate (ATP) gradually decreased $(\mathrm{P} \leq 0.05)$ with processing time. Adenosine diphoshate (ADP) and adenosine monophosphate (AMP) were not affected by processing time. Inosine monophosphate (IMP) and inosine (INO) increased $(\mathrm{P} \leq 0.05)$ to $48 \mathrm{~h}$ postharvest. Hypoxanthine remained constant after $0 \mathrm{~h}$ postharvest. In conclusion, rainbow trout could be processed at $0 \mathrm{~h}$ postharvest without negatively affecting product quality.
\end{abstract}




\section{ACKNOWLEDGEMENTS}

I wish to express my sincere thanks to my graduate supervisor, Prof. B. Kenney, for his mentoring and support throughout my study. Thank you for giving me this opportunity and your guidance, which made the completion of this work possible.

Also, I want to extend my gratitude to my advisory committee members, Jacek Jaczynski, Ph.D, Hillar Klandorf, Ph.D for their valuable advice and suggestions.

Special thanks go to Susie Slider for her great help during the course of laboratory work and practical advice in scientific work and writing. I wish to express my thanks and gratitude to Auchalee Aussanasuwannakul and Megan Manor for their technical expertise.

I would like to also acknowledge all of the graduate students in the Animal Nutrition and Sciences for their help and support. They were a constant source of inspiration to me in my research and personal growth.

Thanks to my darling husband Adebisi Adeniyi for his love, encouragement, patience, understanding, endless support, and provision, and to my two sons Adeboye Adebisi and Adejare Adebisi thanks for your patience and usual joy you are always giving me. Each day, I have been blessed with a great family which has always been there for me.

The last acknowledgment is dedicated to my family. My parents and parent in-laws for their support and love throughout these years. My parents' inspiration has pushed me to exceed my own expectations and strive for goals that seemed unreachable, but now are within my grasp. 


\section{TABLE OF CONTENTS}

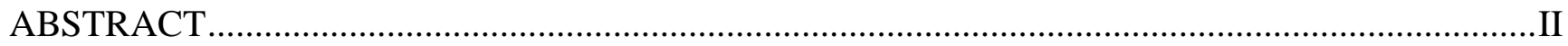

ACKNOWLEDGEMENTS ................................................................................................. III

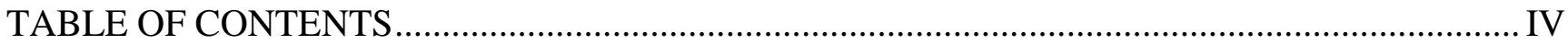

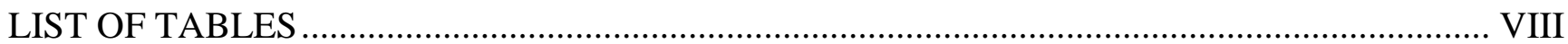

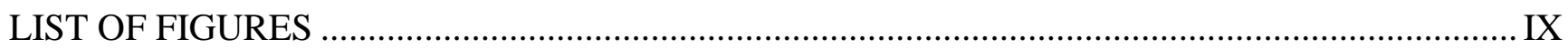

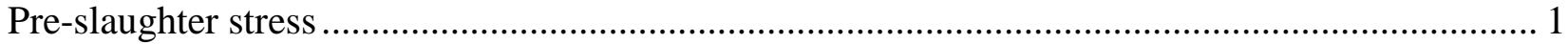

Definition of stress...................................................................................................... 1

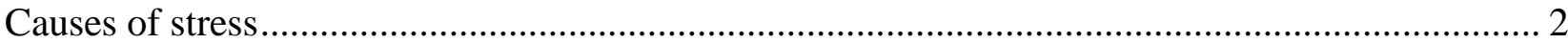

Pre-slaughter handling ............................................................................................ 2

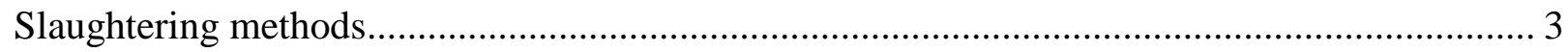

Water Temperature before and Chilling temperature after slaughter .................................... 4

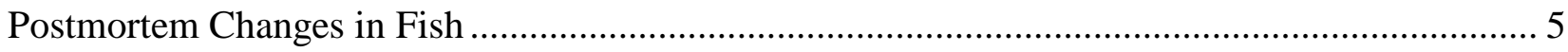

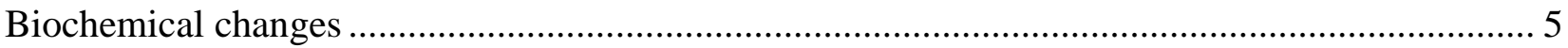

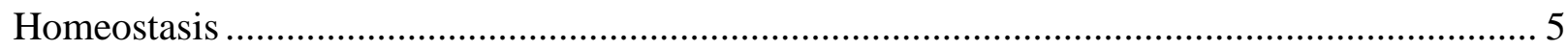

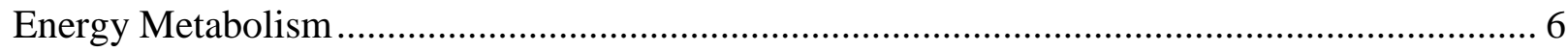

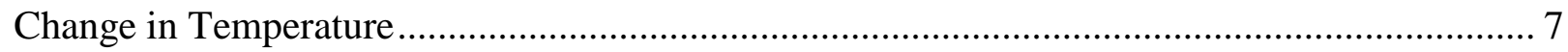

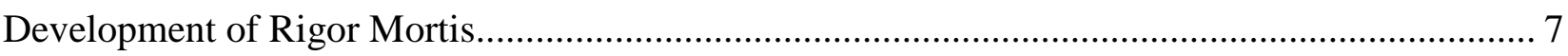

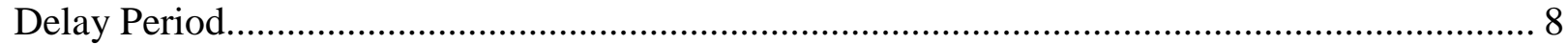

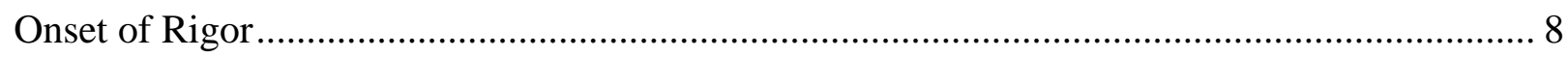


Resolution of Rigor Mortis .................................................................................................. 9

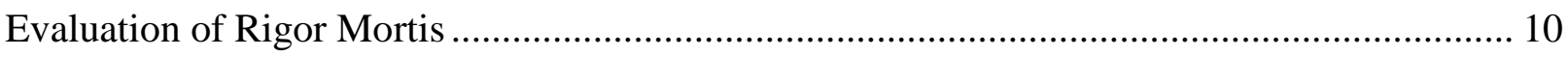

Fish Processing, Fillet Quality and Rigor Development .............................................................. 10

Pre-Rigor Filleting / Post-Rigor Filleting ................................................................................. 11

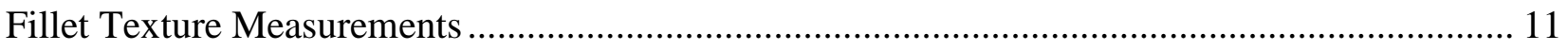

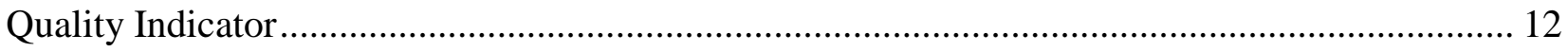

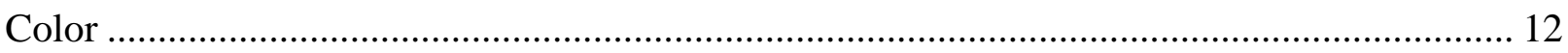

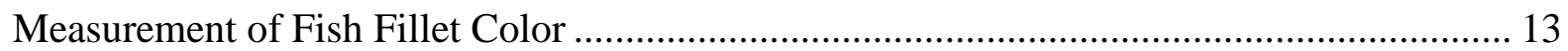

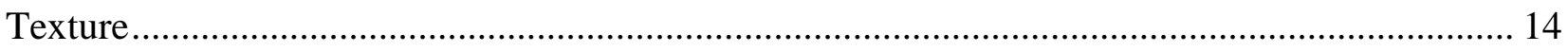

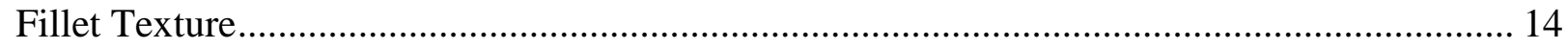

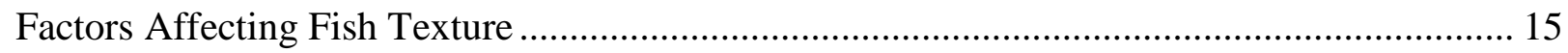

Ante-Mortem Factor........................................................................................................ 15

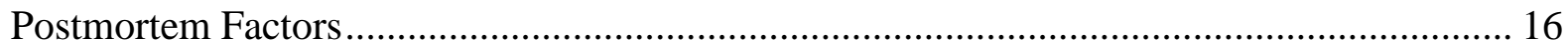

Comparison of Adenine Nucleotide Degradation/Catabolism in Stressed and Nonstressed Fish . 18

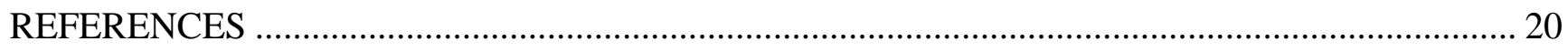

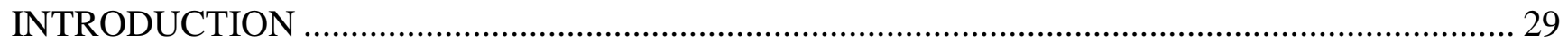

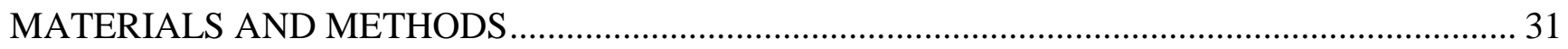

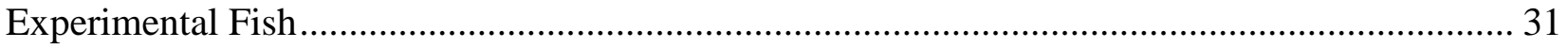

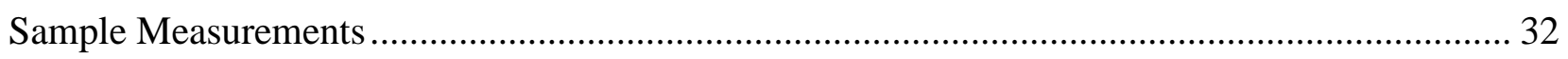

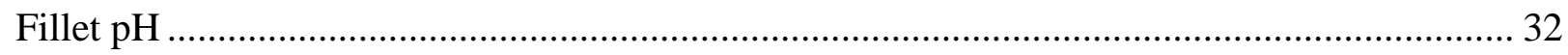

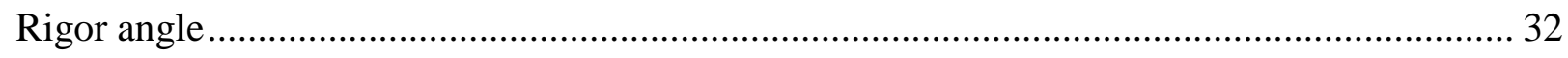




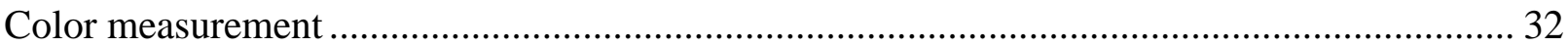

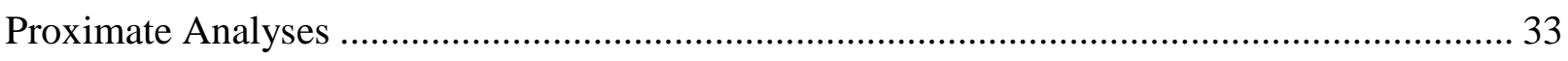

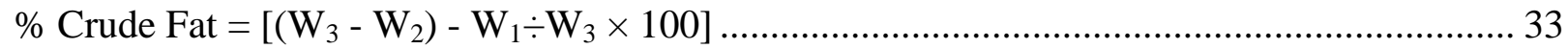

Percent fillet shortening, myotome length, and fillet temperature....................................... 34

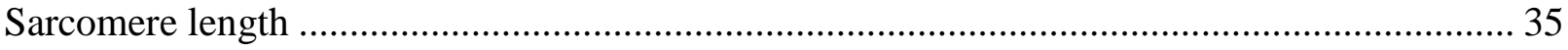

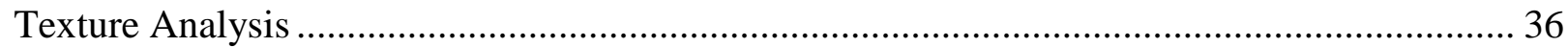

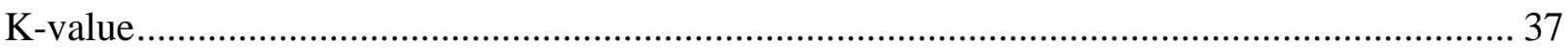

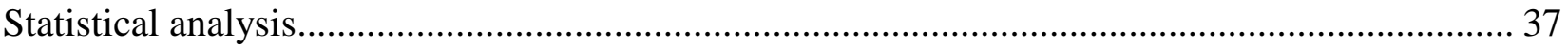

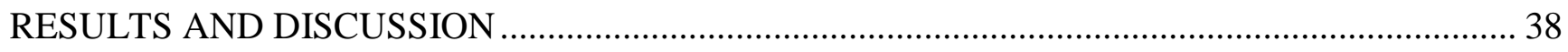

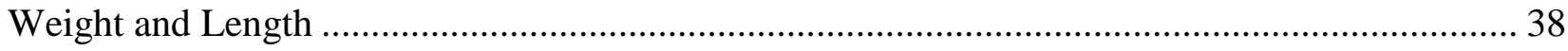

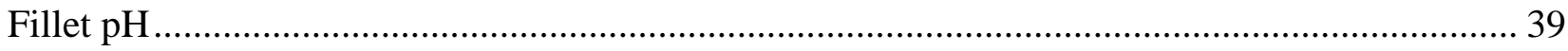

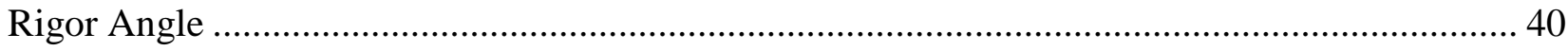

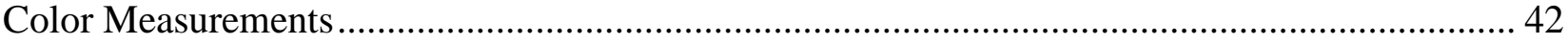

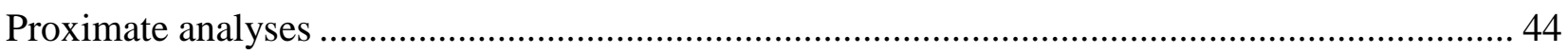

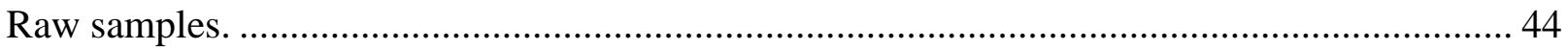

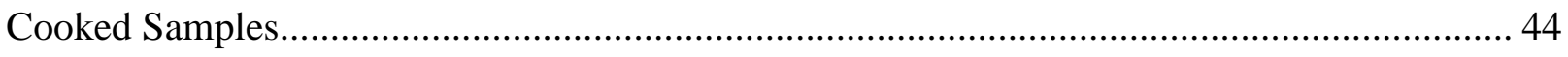

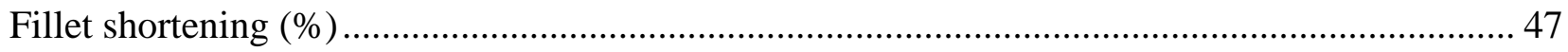

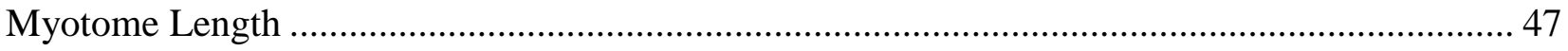

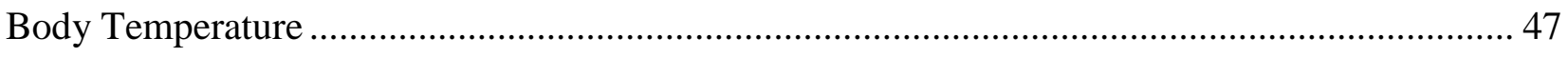

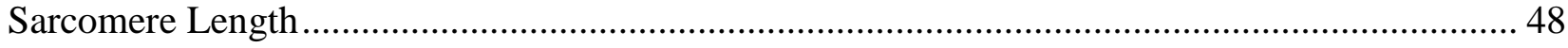

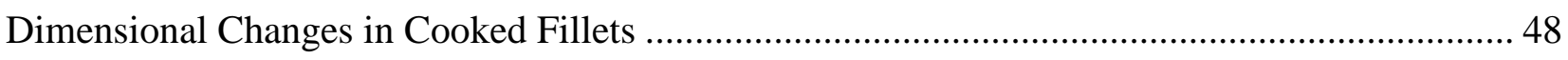

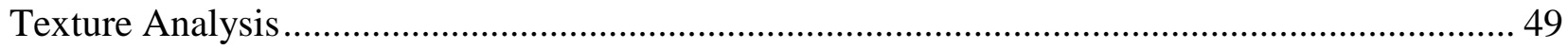




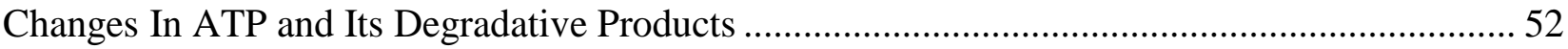

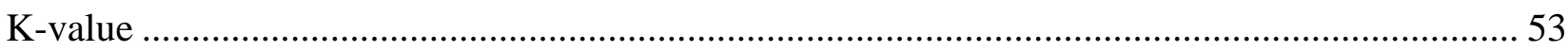

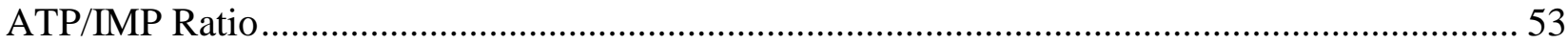

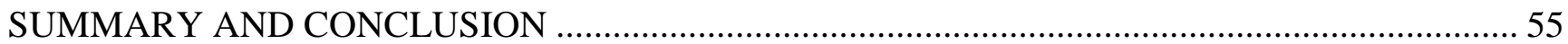

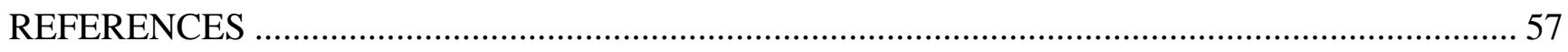

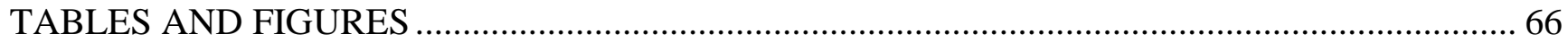

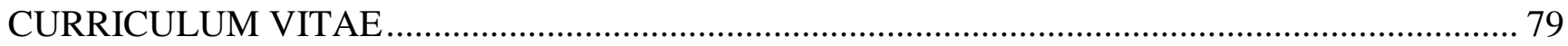




\section{LIST OF TABLES}

Table 1: Biological characteristics of rainbow trout (Oncorhynchus mykiss) fillets processed at different postharvest periods.

Table 2: Average fillet color ( $\mathrm{L}^{*}, \mathrm{a}^{*}$, and $\mathrm{b}^{*}$ ) of rainbow trout processed at different postharvest periods: $0 \mathrm{~h}$ postharvest, $24 \mathrm{~h}$ postharvest and $48 \mathrm{~h}$ postharvest.......................................... 69

Table 3: Proximate composition of raw trout fillets at different time postharvest. .......................... 70

Table 4: Effects of processing times on proximate composition of cooked rainbow trout fillet..... 70

Table 5: Changes in fillet shortening (\%), myotome length, and body temperature in rainbow trout processed at different times after harvest............................................................................. 71

Table 6: Changes in length, width, maximum height, and area of cooked rainbow trout fillet at different processing and storage periods. 


\section{LIST OF FIGURES}

Figure 1: Muscle pH of rainbow trout filleted at 0,24 and $48 \mathrm{~h}$ postharvest ................................. 67

Figure 2: Effect of time postmortem on rigor development.. ................................................... 68

Figure 3: Sarcomere length of rainbow trout fillet processed at different postharvest periods............. 72

Figure 4: Allo-Kramer and Variable blade shear force of rainbow trout fillets processed at different

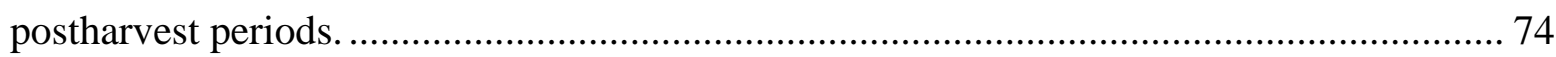

Figure 5: Allo-Kramer and Variable blade shear energyof rainbow trout fillet processed at different

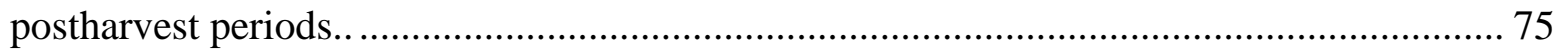

Figure 6: Changes in nucleotide content in muscle of rainbow trout processed at different postharvest periods. 76

Figure 7: Changes in K-value of rainbow trout muscle processed at different postharvest periods. .... 77

Figure 8: ATP: IMP ratio in muscle of rainbow trout processed at different postharvest periods. $\quad$..... 78 


\section{LITERATURE REVIEW}

\section{Pre-slaughter stress}

Stress in fish can be characterized by physiological changes in plasma cortisol, glucose, lactate, and electrolyte concentrations, and these changes are quantitatively related to the severity and longevity of the stressor. Most studies on the physiology of stress in fish species have concentrated, predominately, on the effects of common stressors related to handling procedures in aquaculture. Molinero and Gonzalez (1995) stated that stress in fish can be associated with changes in environmental parameters or acute disturbances caused by management procedures usually involved in fish culture and in experimental procedures. Most research has been done on the effects of acute and chronic stress (Pickering and Stewart 1984). Several studies also demonstrated that specie differences exist in the magnitude and duration of the stress response to various stressors (Davis and Parker 1983); thus, it is important to study the stress responses of each specie reared in captivity (Robertson and others 1988).

Physical disturbance and handling of fish species are common and often unavoidable; features of many experimental investigations such as responses of fish to stress during harvest are also integral components of intensive cultivation systems. In wild fish, stress responses can be seen as physiological and behavioral processes that have evolved to enable fish to mobilize energy reserves in an attempt to cope with an immediate threat. Examples of stressors in fish are water temperature, handling of the fish during and after harvest, and slaughtering methods (Barton and Iwama 1991).

\section{Definition of stress}

Moberg (2000) defined stress as the biological responses created when an individual identifies a threat in the context of homeostasis. Ante mortem stress strongly influences fish physiology and postmortem biochemical processes that turn muscle to meat. Stress can affect the time course of rigor onset (indicator of pre-mortem stress) and overall muscle food qualities in terms of color, texture, and flavor (Lowe and others 1993). Therefore, it is very important to maintain a good relationship 
between pre-slaughter management and slaughter methods by minimizing stress when carrying out the procedure so as to have a good final product. Albeit, there are inevitable conditions where stressors interact and affect the final product. Several factors can induce stress responses in fish such as adverse water quality, crowding, improper feeding, chronic disturbances, harvesting and handling, water temperature, and slaughtering methods. Pre-slaughter procedures, such as crowding during capture impose significant stress on fish by increasing cortisol. Haard (1992) reported that postmortem disorders, caused by a stressful ante mortem environment immediately prior to slaughtering, are responsible for texture and flavor of refrigerated meat. Sigholt and others (1997) reported that stress lowered the breaking strength of Atlantic salmon (Salmo salar) muscle, and hence produced soft fillets. In agreement, Hole (1999) indicated that stress in Salmon produces soft fillet. Stressed salmon had stronger rigor contraction and softer muscle than unstressed fish (Erikson and others 1997). After stress is removed, metabolism and plasma level of stress hormones gradually return to resting status (recovery). Hormone release is considered a primary response to stress; whereas, the effect on metabolism is considered a secondary response.

\section{Causes of stress}

\section{Pre-slaughter handling}

Continuous handling stress alters rigor state and meat quality (Berg and others 1997). Choosing the most suitable methods for capture before slaughter is an important step in assuring fish quality (Marx and others 1997). The most common method used to capture fish species is netting. Research studies evaluated effects of netting on stress response in fish. Pre-slaughter crowding stress speeds up ATP break down (Erikson and others 1997). Bosworth and others (2000) reported effects of confinement during harvest on catfish. Cortisol levels were lower for unstressed than for stressed 
catfish. Capture, handling, and transportation are traumatic events that may cause considerable physiological reactions in fish. The general adaptation syndrome (GAS) such as stress syndrome (Selye 1956) causes release of adrenalin and cortisol. This release is followed by secondary changes such as increased muscle activity, mobilization of energy stores in muscle and liver, and changes in acid-base balance. Increased blood plasma ion concentrations and reduced tissue water content for fish in seawater may be observed (Mazeaud and Mazeaud 1981).

Stress and muscle activity during transport, netting, and stunning may shorten the time for rigor onset in fish. Stressed fish may develop deeper rigor mortis (Nakayama and others 1992), which may affect texture. A more rapid rise in K-value have been reported in stressed fish (Lowe and others 1993). Handling and processing fish during rigor can result in loss of quality and lower fillet yield (Lave'ty 1984).

\section{Slaughtering methods}

Several authors have discovered that slaughter method had important effects on the biochemical changes in postmortem fish muscle. These responses occur especially in rainbow trout (Oncorhynchus mykiss) that are usually slaughtered by removal from water resulting in death by anoxia. Choosing the most suitable method for stunning prior to slaughter is an important step to ensure an optimal time course for rigor onset (long duration of time) and thus, meat quality. Slaughter methods that act quickly and minimize reactions in fishes are favorable due to reduced stress resulting improved in muscle food quality (Marx et al 1997; Robb and others 2000; Roth and others 2002; Stien and others 2005). Research reported that percussion, $\mathrm{CO}_{2}$, and electrical stunning are reliable stunning methods. Slaughtering methods could cause stress if not used properly. The most stressful is carbon 
dioxide; fish exhibit an avoidance behavior that quickly depletes high-energy phosphogens and gives rise to early onset of rigor (Thomas and others 1999). In contrast, Papinaho and others (1995) reported that electrical stunning prior to slaughter is the best method to minimize perimortem struggle slowing the onset of rigor mortis. Similarly, Azam and others (1989); Mochizuki and Sato (1994); Marx and others (1997) reported that exposure of fish, especially rainbow trout, to electricity attain physiological consequences by minimizing struggle and blocking future stimulation of muscle by the autonomous nervous system. Robb and others 2000 revealed that electrical stimulation of fish muscle hasten onset of rigor mortis depending on duration, frequency, and electric current /voltage. In order for a fish to be stunned, $100 \mathrm{~mA}$ at $50 \mathrm{~Hz}$ and $115 \mathrm{~V}$ should be used as a minimum current. Also, percussive stunning is one of the best methods of slaughtering. This operation is performed as a blow to the head-using a wooden or plastic stick.

\section{Water Temperature before and Chilling temperature after slaughter}

A primary factor affecting rigor, muscle quality, and shelf life in fish, through its effect on postmortem, enzymatic, and microbial activity is temperature (Sikorski 1989). Fish should be chilled quickly to the temperature of melting ice soon after capture and maintained at that temperature (FAO/WHO 1977; FAO 1982). However, ante-mortem handling affects quality of fish muscle. Rigor onset depends on the fish species, water temperature, and temperature of pre-rigor storage (Azam and others 1989; Lowe and others 1993; Sigholt and others 1997; Jerret and others 1989). In farmed fish, stress is easy to control by technical measures but it takes a while before rigor onset. Meanwhile in wild-caught fish, rigor onset is difficult to control; rigor occurs within an hour of harvest (Love 1980). Skjervold and others $(1996,1999)$ showed that fish can be chilled in sea water at a temperature of $1^{\circ} \mathrm{C}$ 
for 30-60 minutes to a core temperature below $4^{\circ} \mathrm{C}$ before being slaughter. This cooling protocol, with reduced stress, delayed rigor onset in Atlantic salmon by up to 5-6 days.

\section{Postmortem Changes in Fish}

\section{Biochemical changes}

Several researchers have addressed fish physiology prior to harvest and slaughter methods in describing muscle chemical changes, postmortem (Azam and others 1989; Sigholt and others 1997; Skjervold and others 1999; Ruff and others 2002). Fish struggle during capture, damaging them physically and accelerating postmortem metabolism; these events can negatively affect quality (Lowe and others 1993). As soon as fish are slaughtered, a series of biochemical events are initiated in its body. The most important, which is responsible for rigor mortis, is the breaking down/degradation of tissue components immediately after death. Five of these components are carbohydrates, nucleotides, protein, fats, and nucleic acids. The depletion of muscle energy stores, specifically glycogen, leads to the disappearance of ATP. Because ATP maintains muscle in an extensible state, permanent crossbridges form between myosin and actin when ATP is depleted and thus, leads to stiffness of the muscle (Haard 1992) described as rigor mortis.

\section{Homeostasis}

At death, the supply of oxygen to fish muscle is interrupted because blood is no longer pumped by the heart and is not circulated through the gill. Since there is no available oxygen, for respiration then energy produced from ingested nutrients is greatly limited. In cat fish, Salmon, rainbow trout, and cod, stored carbohydrate (glycogen) is oxidized by muscle enzymes producing carbon dioxide $\left(\mathrm{CO}_{2}\right)$, water, and Adenosine triphosphate (ATP) following a series of biochemical reactions. Respiration reactions can be categorized as aerobic and anaerobic. 


\section{Energy Metabolism}

When fish are dead and blood circulation ceases, individual cells will continue to function until the remaining oxygen is used up within the muscle, and the electron transport system starts to fail. To maintain homeostasis, when aerobic metabolism ceases, anaerobic metabolism continues. During anaerobic metabolism, glycogen stored in liver cells and muscle will be hydrolyzed to glucose by an enzyme called glycogen phosphorylase. Glucose degrades to two pyruvic acids with the production of 8 ATP. Then, in absence of oxygen, two pyruvic acids molecules are converted to two lactic acids molecules and two ATPs from each glucose. This lactic acid accumulates in fish muscle and lowers its $\mathrm{pH}$. The production of lactic acid continues until muscle glycogen is depleted. Salmon fillet $\mathrm{pH}$ dropped from 7.5 to 6.4/6.7 (Jerrett and others 1996; Robb and others 2000; Sigholt and others 1997), and in cod pH dropped from 6.8 - 6.1/6.5. Chiba and others (1991) reported a $0.5 \mathrm{pH}$ decrease within 3h in one-minute stressed fish compared to unstressed fish whose $\mathrm{pH}$ dropped only by 0.10 units at the same time. Robb and others (2000); Einen \& Thomassen (1998) also reported that a low pH $(<7.0)$ immediately after death in some fish species is considered the result of harvesting stress.

Rigor mortis development is the direct result of ATP depletion (Berg and others 1997; Erikson 2001; Poli and others 2003; Scherer and others 2005; Stien and others 2005). Several studies have shown a relationship between increased exercise before death, muscle ATP depletion, and time of rigor onset in different fish species depletes energy reserves in the muscles resulting in $\mathrm{pH}$ change (Lowe and others 1993; Nakayama and others 1996; Berg and others1997; Sigholt and others 1997; Skjervold and others 2001b; Jittinandana and others 2003; Scherer and others 2005). 


\section{Change in Temperature}

Fish body temperature is of utmost importance to onset and duration of rigor mortis. At a higher temperature, rigor occurs sooner and faster. This response is explained by enzymatic reactions where reaction speed increases with increased temperature. High temperatures cause protein denaturation that reduces water holding ability of fish muscle. Usually, as a result of delayed rigor onset and prolonged rigor development, colder temperatures increase storage life of fish and its use for consumption are extended. Previous studies on Salmon showed that low pre-mortem temperature does cause a delay in rigor mortis (Jerrett and others 1998; Skjervold and others 1999; Skjervold and others 2001a). Abe and Okuma (1990) stated that low muscle temperature at death slows down rigor processes. This response was noted in many temperate and tropical fish species such as red sea beam, salmon, and tilapia. Pre-chilling is an effective method of slowing down the biochemical reactions brought on by stress in fish before they are slaughtered, and this method delays the onset, attainment, and subsequent resolution of rigor mortis (Skjervold and others 2001). Roth and others (2006) showed that live chilling stimulates primary stress responses, and low internal temperature at slaughter delays onset of rigor mortis. Cold shortening has been recognized as a serious quality defect for meat of terrestrial animal origin since the beginning of meat quality research. In some fish species, cold shortening may be related to $\mathrm{Ca}^{2+}$ leaks at low temperature. Storage temperature is an important factor affecting quality and shelf life of fish (Dawood and others 1986; Whittle 1996). Shelf-life of channel catfish is less than 8 days at $0^{\circ} \mathrm{C}$ and 4 days at $10^{\circ} \mathrm{C}$ (Silva and others 1993).

\section{Development of Rigor Mortis}

A consequence of ATP disappearance in postmortem muscle is the development of rigor mortis. Rigor mortis develops due to the formation of irreversible cross bridges between myosin and 
actin by a similar reaction that forms actomyosin during muscle contraction (Haard 1992). Generally, rigor mortis in fish has a shorter duration than in mammals depending on the storage temperature. Its peak in slaughtered fish, kept in ice, lies between 5 and $22 \mathrm{~h}$ after death for marine fish. The total duration of rigor covers 30-120h for marine fish and 72-80h for freshwater fish. Overcrowded fish not held on ice show a shorter period of muscle toughening (32-93h). The pre-rigor time frame depends on physiological conditions before and after death.

\section{Delay Period}

The delay period prior to rigor onset is the first stage of postmortem changes. Fish in this state are fresh. The muscle remains elastic and has a degree of softness that changes after death. The degree of softness of fish muscle in vivo is the "original softness level" this softness is maintained for a certain period of time after death. This period is called the pre-rigor period or lag period. The time lag from death to onset of rigor mortis is called "Lag of initiation".

\section{Onset of Rigor}

Rigor mortis is the first postmortem process that has a major effect on the appearance and structure of fish muscle (Berg and others 1997). When fish are killed while relaxed, creatine phosphate is degraded prior to ATP breakdown (Iwamoto and others 1988). When creatine phosphate and ATP reach the same concentration, ATP content begins to decrease resulting in the stiffness of muscle (Watabe and others 1991) and muscle enters full rigor mortis (Iwamoto and others 1987). The onset of rigor mortis occurs when ATP content of the muscle drops below a critical level. Rigor mortis occurs upon depletion of ATP in the muscle to the point where cross-bridge cycling between actin and myosin filaments stop, and therefore, detachment of the filaments is halted. Thus, permanent actomyosin cross-bridges form (Pate and Brokaw 1980). Since detachment of myosin and actin 
filaments is ATP dependent, the time elapsed post mortem prior to the onset of rigor mortis is affected by ATP content at death, which in turn is affected by handling stress (Lowe and others 1993). In rested fish, full rigor was observed $12 \mathrm{~h}$ after harvest, and for a more conventional simulated harvest, full rigor was recorded within 3 h. In stressed Atlantic salmon (Salmon salar), full rigor was observed between 6 and 24 h postmortem (Berg and others 1997; Sigholt and others 1997; Skjervold and others 2001). Pawar and Magar (1965) reported that unstressed tilapia (Tilapia mossanbica), at $2^{\circ} \mathrm{C}$, entered

onset of rigor mortis after $2 \mathrm{~h}$, reached full rigor at $7.5 \mathrm{~h}$, and resolved at $11.5 \mathrm{~h}$. Abe and Okuma (1990) observed that carp and rainbow trout entered full rigor within $24 \mathrm{~h}$ after death. Mochizuki and Sato (1994) found no difference in the rate of rigor at $0^{\circ} \mathrm{C}$ and $8^{\circ} \mathrm{C}$ in mackerel.

Rigor state when fish are filleted, affects muscle quality. Pre-rigor fillets contract and shorten during filleting because these muscles have no skeletal restraint. While, in-rigor, fish are usually stiff, leading to poor fillet yield; rough handling of these fish can cause gaping.

\section{Resolution of Rigor Mortis}

During the resolution of rigor mortis muscle gradually loses its stiffness and softens. Softening continues until fillet firmness returns to its original level or becomes softer. Rigor mortis is said to be completely resolved when fish tissue softness reaches the original level. Gradual muscle softening continues unabated even after termination of rigor mortis, resulting in muscle softness beyond the original level. Possible causes of postmortem tenderization include a weakening of Z-discs due to their hydrolysis by endogenous proteases (Seki and Tsuchiya 1991), a degradation of connective tissue (Ando and others 1993), or a weakening of myosin-actin junctions (Yamanoue and Takahashi 1988). In salmon resolution of rigor occurs within 2-4 days after slaughtering in unstressed tilapia, resolution 
of rigor occurs within 25-26h (Iwamoto and others 1987; Korhonen and others 1990; Nakayama and others 1992). Rainbow trout and carp, stored at $5^{\circ} \mathrm{C}$, did not show any resolution (Bito and others 1983).

Z-lines are made up of the protein $\alpha$-actinin, and towards the end of rigor mortis, autolysis begin. Tissue proteins are hydrolyzed by proteolytic enzymes, particularly the cathepsins. Cathepsins are the most important acid proteases; their activity is enhanced after death due to a lower tissue $\mathrm{pH}$ (trout- 6.5, tilapia- 6.1, salmon- 6.4, and catfish- 6.2) resulting from accumulation of lactic acid. When the protein, $\alpha$-actinin of the Z-lines is hydrolyzed, actin filaments lose their anchor points, and this cytoskeletal weakening results in muscle softening during resolution of rigor mortis.

\section{Evaluation of Rigor Mortis}

Several methods are used to evaluate rigor mortis, and they are grouped into two categories: direct and indirect methods. Direct methods of evaluation are based on changes in physical and mechanical properties of the fish. Korhonen and others(1990) showed that rigor progress could be evaluated by assessing extent of sag in whole fish; Nakayama and others (1992) reported that rigor progress could be evaluated by monitoring isometric muscle strength (Montero and Borderias 1992); Bito and others (1983) used rigidity/rigor index as an indicator of fish flexibility in another method of evaluating rigor progress. Indirect methods measure changes in $\mathrm{pH}$ and in the concentration of ATP and its catabolites (Iwamato and others 1987)

\section{Fish Processing, Fillet Quality and Rigor Development}

Rigor mortis has a remarkable influence on the quality of fresh and processed fish. The extent to which rigor affects fillet quality depends on temperature, rate and extent of $\mathrm{pH}$ decline at death, and rate of rigor onset. In frozen whole fish, rigor influenced quality as evidenced by gaping and increased 
toughness. In frozen fillets used in the manufacture of smoked fish, rapid rigor onset adversely affects quality through increased product shrinkage, fillet toughness, and drip loss. Sorensen and others (1997) and Einen and others (2002) reported that farmed Salmon and wild caught fish are filleted in a traditional manner after the resolution of rigor mortis at 3-5days after death. Placing salmon in a chilling tank 30-60 minutes before slaughter resulted in a low temperature, and thus, a longer time prior to onset and resolution of rigor mortis (Skjervold and others 1999). Skjervold and others (2001a) suggested that the pre-chilling facilitates pre-rigor filleting.

\section{Pre-Rigor Filleting / Post-Rigor Filleting}

Fillets are obtained by cutting a fish longitudinally along both sides of the backbone, yielding right and left fillets. Several studies have investigated how pre- and post-rigor filleting affects muscle quality. Pre-harvest stress induces an extra strong rigor tension that causes gaping (Robb and others 2000; Kristoffersen and others 2006) as a result of the high temperature when the muscle goes into rigor. Sorensen and others (1997) showed that fish fillets processed pre-rigor are firmer than fillets produced post rigor. In agreement, Esaiassen and others (2006) showed that salmon fillets are thicker and shorter and have a firmer texture and less gaping when filleted pre-rigor. In addition, Skjervold and others (2001a) reported more gaping on day 14 than day 7 of storage in salmon fillets. They concluded that post rigor processing resulted in a higher degree of gaping than pre-rigor filleting. Therefore, fillets frozen pre-rigor may yield acceptable products if carefully thawed at low temperatures $\left(-17^{\circ} \mathrm{C}\right)$, allowing rigor mortis to pass while the muscle is still frozen.

\section{Fillet Texture Measurements}

Fillet texture is measured as the toughness and softness of the muscle. Among several methods, Warner-Bratzler shear force (Veland and others 1999) and Kramer shear/ compression cell measures 
(Dunajski 1979; Gill and others 1979; Lefevre 1997; and Gomez-Guillen and others 2000) are the most accurate approaches for measuring the texture of fish fillets. The Kramer shear cell is the most commonly used texture attachment used in measuring fish fillet firmness. The Kramer shear cell is a multi-blade (5 blades) tool where results are a combination of shear and compression forces. For measurement of texture, the instrument is first placed perpendicular to the fillet; then, the blade is pushed into the flesh by applying compressive force. Muscle fiber direction is very important in determining, accurately, fish fillet texture. Lefevre (1997) confirmed the effectiveness of the Kramer shear force at a perpendicular direction in determining fillet texture.

\section{Quality Indicator}

A variety of attributes are considered as quality indicators in determining fillet freshness: these factors may include color, shear force value, and muscle $\mathrm{pH}$.

\section{Color}

One of the quality attributes affected by pre-slaughter condition is color; color determines consumer preference. Francis (1995) defined color as a key symbol of food items that affects consumer perception. Anderson (2000) concluded that color perform major role in evaluating the quality of processed fish. A white flesh fillet color in Nile tilapia, Oreochromis niloticus, and red tilapia, Oreochromis sp. is preferred by consumers in the U. S.; pink-red in rainbow trout, and red in Atlantic salmon and trout (Gormley 1992; Alfnes and others 2006; Anderson 2000; Fish Farming International 2003) are preferred colors. Consumers preferred pink color for smoked salmon fish (Gormley 1992).

Pre-slaughter stress at slaughter also affects muscle color attributes of fish (Love 1988; Erikson 2001; Kestin and Warriss 2001. Robb and Warriss (1997) determined that stressed fish with high 
muscle activity at $48 \mathrm{~h}$ slaughtering had lower Roche color scores than unstressed fish when color was evaluated at $24 \mathrm{~h}$. In tuna and salmonids, a high level of pre-slaughter activity leads to lighter, less red, and more translucent flesh color. Robb and others (2000) indicated that slaughter methods could affect carotenoid content which are deposited in the muscle after death due to alteration in muscle structure. Carotenoids are lipid soluble, giving the yellow to red color (Anderson 2000).

\section{Measurement of Fish Fillet Color}

Electronic instruments may be used in measuring the color of fish fillets (Anderson, 2000). Five elements used in color measurement are $a^{*}$ value (red/green), b* value (yellow/blue), L* value (lightness), Hue $\left(\mathrm{H}^{*}\right)$, and chroma $\left(\mathrm{C}^{*}\right)$. Skrede and Storebakken (1986) observed an increase in redness intensity $\left(\mathrm{a}^{*}\right)$ with increasing carotenoid content in Atlantic salmon, while lightness $\left(\mathrm{L}^{*}\right)$ decreased and yellowness (b*) was not affected. A high fat content in farmed salmonid fillets changes color perception (Christiansen and others 1995) and increases $\mathrm{L}^{*}$ and $\mathrm{b}^{*}$ values (Morkore and others 2001). In stressed Arctic char (Salvelinus alpinus), a* value is reduced, and a stress effect on $L^{*}$ value depends on hatching temperature (Jittinandana and others 2003). Salmon, subjected to high stress, had slightly higher $a^{*}$ and $b *$ values.

A greater $\mathrm{pH}$ drop associated with higher perimortem activity, results in increased lightness

(L*). Robb and others (2000) reported that a rapid drop in ATP causes muscle protein (connective tissue in myofibril and collagen in myosepta) to denature, and become insoluble, reducing the net surface charges and thereby releasing water. These changes lead to whiteness and therefore lighter fillets. 


\section{Texture}

\section{Fillet Texture}

The primary aim of the aquaculture industry is to deliver a consistent product to meet consumer taste and demand. Texture is a sensory characteristic important to maintaining consumer demand because it is a major factor determining flesh quality. Hatae and others (1990) explained that fiber size and collagen content affect fish fillet texture. Muscle fibers in fish are the same as in skeletal muscle of higher vertebrates consisting of three major compartments affecting quality of fish muscle (Dunajski 1979). The first is contractile protein organized in myofibrils inside the muscle fibers. This category is a major determinant of textural properties in muscle tissue after cooking. Secondly, lipids are found as the major component of cell membranes, in the form of phospholipids; as storage lipids in adipose tissue; and as lipid droplets in the cytoplasm of muscle fibers. Lipids contribute significantly to fillet quality. And, the third compartment is connective tissue, which is made up of collagen and forms the supporting network of muscle.

The fish fillet is organized into myotomes composed of muscle fibers separated by sheets of connective tissue (myocommata) that are very delicate; myocommata thickness is between 0.12 0.17mm in catfish and cod (Love and others 1972), and it is made up of a network of collagen fibers (Bugeon and others 1999). Cooked fillet firmness is negatively correlated to mean fiber size (Hatae and others, 1990), and the firmness of smoked salmon fillets is associated with a high muscle fiber density (Johnston and others 2000). Connective tissue also contributes to texture, with the firmness of raw muscle being related to collagen content (Hatae and others 1986; Sato and others 1986). There is increased firmness at different locations in salmon (Salmo salar L.) muscle (antero-posterior axis; Sigurgisladottir and others 1999), that may be the result of an increase in collagen content in the 
caudal vs. rostral regions (Montero and Borderias 1989). Softening of muscle after slaughtering is partly due to disintegration of the extracellular matrix (Bremner and Hallett 1986; Ando and others 1991).

\section{Factors Affecting Fish Texture}

Several factors affect textural properties of fish muscle including ante-mortem (age, species, and physiological condition of the fish, slaughtering methods, and nutritional state of the fish) and postmortem variables (temperature of cooking, and $\mathrm{pH}$ ).

\section{Ante-Mortem Factor}

Various perimortem activities that occur before and during harvest may affect texture of fish muscle (Bashuaud and others 2010; Morkore and others 2008; Skjervold and others 2001). Sigholt and others (1997) reported that pre-slaughter stress affects farmed salmon, resulting in soft fillets. Fluctuation in muscle tissue composition, such as fat, water (Izquierdo and others, 2005), and protein content (Hatae and others 1990), may be caused by nutritional and physiological processes, and these changes in composition play an important role in the texture development of fish fillets. Moisture content of a fish fillet before and during processing is indicative of the total amount of moisture and its release from the fillet.

Research had shown that a high-fat diet fed to farmed salmon (Anderson and others 1997) and rainbow trout (Faergemand and others 1995) resulted in a high fat content in the fillet compared to fillets from the same specie fed with a low-fat diet. Whereas, other research observed that fat content does not affect firmness (Rora and others 1998). Albeit, Anderson and others (1997); and Dunajski (1979) reported that softness in the fillet was directly affected by fat in the diet. Also, a smaller fiber diameter results in greater strength and vice-visa (Hatae and others 1990). Kiessling and others (2004) 
and Feargemand and others (1995) showed that slaughter method affects fish fillet texture. In contrast, Azam and others (1998) showed no relationship between slaughter method and texture of rainbow trout. Starvation prior to slaughter affects salmon fillet texture (Einen and Thomassen 1998; Morkore and others 2008). Fish size affects muscle fiber diameter, and fiber diameter is directly proportional to fish texture (Dunajski1979).

\section{Postmortem Factors}

Postmortem biochemical processes play a significant role in the texture development of fish muscle. Postmortem factors affecting texture properties are glycolysis, rigor mortis, contraction of muscle that may lead to gaping (separation of muscle segments), storage temperature, $\mathrm{pH}$, and cooking temperature.

Glycolysis. Upon death, blood flow is stopped, and oxygen is immediately decreased; glycogen is broken down anaerobically to produce ATP via substrate-level phosphorylation, and lactic acid accumulates. Muscles are soft and limp during the pre-rigor stage. Lactic acid accumulation causes $\mathrm{pH}$ of fish muscle to drop from 7.0- 6.2. In the acidic environment, biochemical changes occur, and actin and myosin form permanent crossbridges. Ando and others (1999) suggested that bleeding reduces the activity of proteolytic enzymes causing a delay in softening of fish texture.

Rigor mortis. Rigor mortis is an important process resulting from the depletion of ATP and, the rate of onset and resolution plays a major role in fish muscle texture. Immediately after death, fish muscle is soft, plastic, and extensible. ATP and glycogen are depleted resulting in the formation of actomyosin and shortening of the sarcomere. Then, fish muscle becomes tough, firm, and inextensible through muscle shortening. After some time there is a transition in the texture of the muscle from hard to soft, indicative of the post-rigor stage. However, Toyohara and Shimizu (1988); Ando and others 
(1991); and Chiba and others (1991) showed that softness post rigor is not a result of resolution of rigor. Stress posed on fish fillets during shortening results in separation of the myotomes at the myosepta.

Gaping. Gaping is the phenomenon observed when myotomes of fish muscle separate resulting in broken tissue and a rough appearance (Love 1970). The relationship between forces pulling muscle apart and the strength and integrity of fish muscle causes gaping. Robb and Kestin (2002) reported that biochemical changes resulting in gaping may be the result of variation in slaughtering methods. Morkore and Rorvik (2001) reported that gaping could occur even when the flesh is firm. Sato and others (1991), Bremner and Hallet (1985); Bremner and Hallet (1986); Monkore and Bordenias (1990)) suggested that storage temperature and time affect the formation of tissue flakes as a result of gaping.

Storage temperature, time, and $\mathbf{p H}$. The rate and extent of separation between myotomes of fish fillets are influenced by temperature, time, and $\mathrm{pH}$. Fillet $\mathrm{pH}$ also plays as important a role as temperature in fillet texture development. Love and others (1972) showed that $\mathrm{pH}$ status altered the strength of the myocommata. Gaping increased with lower $\mathrm{pH}$ as a result of low connective tissue strength. Love (1983) reported that cooked cod, with a pH above 7, was softer and tenderer. Cooking Temperature; Textural changes during cooking are connected with changes in myofibrillar and stromal proteins. At temperatures above $60^{\circ} \mathrm{C}$, myofibrils shrink and muscle toughens, while stromal proteins are hydrolyzed and connective tissue weakens. The relationship between shear force and temperature is dependent on fillet $\mathrm{pH}$. Fresh fish cooked at a high temperature go into rigor faster and are always tough. 


\section{Comparison of Adenine Nucleotide Degradation/Catabolism in Stressed and Nonstressed Fish}

Adenine nucleotides and their degradation products have been used as chemical indices of freshness in fish. Endogenous enzymes degrade adenine nucleotides during the early stages of the storage period (Boyle and others 1991). In postmortem fish muscle, degradation of adenosine-5triphosphate (ATP) takes place according to the following sequence: ATP $\rightarrow$ adenosine-5_-diphosphate $(\mathrm{ADP}) \rightarrow$ adenosine-5_-monophosphate $(\mathrm{AMP}) \rightarrow$ inosine-5_-monophosphate $(\mathrm{IMP}) \rightarrow$ inosine $(\mathrm{HxR})$ $\rightarrow$ hypoxanthine (Hx) $\rightarrow$ xanthine (X) (Ehira and Uchiyama 1987; Vázquez-Ortiz and others 1997). In most fish postharvest, the initial catabolism of ATP normally results in a fast and temporary accumulation of IMP, an intermediate metabolite that contributes to the pleasant, fresh flavor of the fillet. Degradation of IMP to HxR and finally to Hx occurs at a slower rate and is due to, at least in part, action of enzymes from spoilage-causing microorganisms (Surette and others 1988). Hypoxanthine accumulation contributes to the progressive loss of desirable fresh fish flavor (Fletcher and Statham 1988).

Microbial metabolism contributes to degradation toward the later stages of storage (Surette and others 1988). Rapid breakdown of ATP before slaughter results in an increase in degradation metabolites (Korhoren and others 1990, Mochizuki and Sato 1994, and Berg and others, 1997) thereby, affecting freshness. An indication of freshness, $\mathrm{K}$ value, is based on ATP breakdown due to respiratory cell death and later formation of nucleotide by-products (inosine monophosphate, inosine, and hypoxanthine). Saito and others (1959) reported that a lower K value indicates a lower rate of ATP glycolysis, and thus, a fresher fish. Fish stress at slaughter leads to a rapid loss in ATP resulting in an increase in K value (Lowe and others 1993; Erickson and others 1997). Fish slaughtered at the same time, but under less stress, were fresher than those that were stressed (Robb and others 2000). 
Therefore, there is a need to minimize fillet quality variation. Inconsistent fillet quality can reduce consumer demand. Variation can be minimized by managing stress prior to slaughter, leading to improved overall quality. At the same time, fillet quality could be maximized, if pre-slaughter conditions are carefully maintained and if fish are processed at an optimal time under optimal conditions. 


\section{References}

Abe H, Okuma E, 1991. Rigor-mortis progress of carp acclimated to different water temperatures. Nippon Suisan Gakkaishi 57, 2095-2100.

Alfnes F, Guttormsen AG, Steine G, Kolstad K. 2006. Consumer' willingness to pay for the color of salmon: A choice experiment with real economic incentives. Am J Agric. Econ 88: 1050-61.

Anderson S. 2000. Salmon Color and the Consumer. Proceeding of the IIFET 2000 International Institute of Fisheries Economics and trade, Oregon State University, July 10-14, Corvallis, Oregon, USA.

Andersen UB, Thomassen MS, Rora MB. 1997. Texture properties of farmed rainbow trout (Oncorhynchus mykiss): Effects of diet, muscle fat content and time of storage, J Sci Food Agric 74: 347-353.

Ando M. 1999. Correspondence of collagen to the softening of meat during refrigeration. In: Sato K, Sakaguchi M, Bremner HA, editors. Extracellular matrix of fish and shellfish. Trivandrum, India: Research Signpost. p 69-79.

Ando S, Mori Y, Nakamura K, Sugawara A. 1993. Characteristic of lipid accumulation types in five species of fish. Nippon Suisan Gakkaishi; 59: 1559-1564.

Ando M. Toyohara H. Shimizu Y. Sakaguchi, M. 1991. Post-mortem tenderization of rainbow trout muscle caused by gradual disintegration of the extracellular matrix structure. J. Sci.Food Agric. 57(6), 1165-1169.

Azam K, Mackie IM, Smith J. 1989. The effect of slaughter method on the quality of rainbow trout Salmo salar. during ice storage. Int. J. Food Sci. Technol. 24: 69-79.

Bahuaud D, Morkore T, Ostbye TK, Veiseth-Kent E, Thomassen MS, Ofstad R. 2010. Muscle structure responses and lysosomal cathepsins B and L in farmed Atlantic salmon (Salmo salar L.) pre- and post-rigor fillets exposed to short and longterm

crowding stress. Food Chemistry. 118 (3): 602-615.

Barton BA, Iwama GK. 1991. Physiological changes in fish from stress, in aquaculture with emphasis on the response and effects of corticosteroids, Annu Rev Fish D: p 3-26.

Berg T, Erikson U, Nordtvedt TS.1997. Rigor mortis assessment of Atlantic salmon (Salmon salar) and effects of stress. J Food Sci 62:439-446.

Bito M, Yamada K, Mikumo Y, Amano K. 1983. Studies on rigor mortis in fish. Differences in the mode of rigor mortis among some varieties of fish by modifies cutting's method. Bull Tokai Reg Fish Res Lab 109:89-96. 
Bosworth BG, Small BC, Mischke CC. 2004. Effects of transport water temperature, aerator type, and oxygen level on channel catfish Ictalurus punctatus fillet quality. J. World Aquac. Soc. 35: 410-417.

Boyle JL, Lisday RC, Stuiber DA. 1991. Adenine nucleotide degradation in modified atmosphere chill-stored fresh fish. J. Food Sci. 56: 1267.

Bremner HA, Hallett I C. 1985. Muscle fiber-connective tissue junctions in the fish blue grenadier (Macruromus novaezelandiae). A scanning electron microscopy study. J Food Sci 50: 975-980.

Bremner HA, Hallett IC. 1986. Degradation in muscle fiber-connective tissue junction in the spotted trevalla (Seriolella punctata) examined by scanning electron microscopy. J Sci Food Agric 37: 1011-1018.

Bugeon J, Veiseth E, Taylor R, Lefevre F, and Fauconneau B.1999. Characterisation histologique du tissu conjonctif intramusculaire de truite. Revue Francaise d’Histotechnologie12:71-80.

Chiba A, Hamaguchi M, Kosaka M, Tokuno T, Asai T, Chichibu S. 1991. Quality Evaluation of fish meat by phosphorus-nuclear magnetic resonance. J Food Sci 56:660-4.

Christiansen R, Struksnaes G, Estermann R, and Torrissen OJ. 1995. Assessment of flesh color in Atlantic salmon (Samo salar) L. Aquaculture Research. 25: 311-321.

Davis KB, Parker NC. 1983. Plasma corticosteroild and chloride dynamics in rainbow trout, Atlantics salmon, and lake trout during and after stress Aquaculture 32:1-2.

Dawood AA, Roy RN, Williams CS. 1986. Effects of delayed icing on the storage life of rainbow trout. J Food Technol 21(2): 159-166.

Dunajski E. 1979. Texture of fish muscle. J Texture Studies 10: 301-318.

Ehira S, Uchiyama H. 1987. Determination of fish freshness using the $K$ value and comments on some other biochemical changes in relation to freshness. In: Kramer DE, Liston J, editors. Seafood Quality Determination. Elsevier. Amsterdam; pp 185-207.

Einen O, Guerin T, Fjaera SO, Skjervold PO. 2002. Freezing of pre-rigor fillets of Atlantic salmon. Aquaculture 212:129-140.

Einen O, Thamassen MS. 1998. Starvation prior in Atlantic salmon (Salmo salar). II. White muscle composition and evaluation of freshness, texture, and color characteristics in raw and cooked fillets. Aquaculture. 169: 37 -53.

Erikson U. 2001. Rigor measurements In: Kestin SC, Warris PD Editors. Framed fish quality. Cornwall, UK. Blackwell publishing. p 283-295. 
Erikson U, Sighlt T, Seland A. 1997. Handling stress and water quality during live transportation and slaughter of Atlantic salmon (Salmon salar). Aquaculture 149: 234-254.

Esaiassen M, Joensen S, Akse L, Tobiassen T, Eilertsen G, and Dahl R. 2006. The temperature in the cold counters-A critical factorfor tray-packed fish. Report 16/2006, ISBN-13 978-82-7251593-4.Tromsø, Norway: Norwegian Institute of Fisheries and Aquaculture Research [in Norwegian].

Faergemand J, Ronsholdt B, Alsted N, Borresen T. 1995. Fillet texture of rainbow trout as affected by feeding strategy, slaughtering procedure and storage post mortem. Water Sci Technol 31: 225231.

FAO. 1982. Reference manual to codes of practice for fish and fishery products. FAO Fisheries Circular. 750 Rome.

FAO 2006. The state of world fisheries and aquaculture 2006. FAO Fisheries technical Paper No. 500. Rome.

FAO/WHO. 1977. Recommended International Code of Practice for Fresh Fish. FAO/WHO, CAC/RCP. 9-176. Rome.

Fish Farming International, 2003. Consumer “Will pay more for Darker Salmon” Study. 30(2):35.

Flecther GC, Corrigan VK, Summers G, Loenard MJ, Jerret AR, Black SE. 2003. Spoilage of rested harvested king salmon (Oncorhynchus tshawytscha). J Food Sci 68: 2810-2816.

Fletcher, G.C. and Statham, J.A. 1988. Shelf-life of sterile yelloweyed mullet (aldrichetta forsteri) at 4C. J Food Sci 53:1030-1039.

Francis FJ. 1995. Quality as influenced by color. Food Quality Pref 6:149-55.

Gill TA, Keith RA, Smith Lall B.1979. Textural deterioration of Red Hake and Haddock muscle in frozen storage as related to chemical parameters and changes in the myofibrillar proteins. $\mathrm{J}$ Food Sci 44: 661-667.

Gomez-guillen MC, Montero P, Hurrado O, Borderias AJ. 2000. Biological characteristics affect the quality of farmed Atlantic salmon and smoked muscle. J Food Sci 65(1): 53-60.

Gormley TR. 1992. A note on consumer preference of smoked salmon color. Irish J Agricultural and Food Research 31:1999-202.

Haard NF. 1992. Technological aspects of extending promotional quality of seafood: A review. J Aqua Food Prod Technol 1:9-27.

Hatae K, Tamari S, Miyanaga K, Mataumoto JJ. 1985. Species difference and changes in the physical properties of fish muscle as freshness decrease. Bull. Jpn. SOCS. ci. Fish.51 (7):1155-1161. 
Hatae K, Tobimatsu A, Takeyama M, Matsumoto J. 1986. Contribution of the connective tissue on the texture difference of various fish species. Bull. J Soc Sci Fish 52:2001-2007.

Hatae K, Yoshimatsu F, Matsumoto JJ. 1990. Role of muscle fibers in contributing firmness of cooked fish.J Food Sci 55: 693-696.

Hole R. 1990. Harvesting salmon for quality fish farmer. 22 (6):43-44.

Iwamoto M, Yamanaka H, Abe H, Ushio H, Watabe S, Hashimoto K. 1988. ATP and creatine phosphate breakdown in spiked plaice muscle during storage, and activities of some enzymes involved. J Food Sci 53(6):1662-1665.

Iwamoto M, Yamanka H., Watabe S, Hashimoto K. 1987. Effects of storage temperature on rigormortis and ATP degradation in plaice Paralichthys oliÍaceus. muscle. J. Food Sci. 52, 15141517.

Izquierdo MS, Montero D, Robaina L, Caballero M, Rosenlund G, Gine's R. 2005. Alterations in fillet fatty acid profile and flesh quality in gilthead seabream (Sparus aurata) fed vegetables oils for a long term period. Recovery of fatty acid profiles by fish oil feeding. Aquaculture 250:431444.

Jerrett AR, Holland AJ, Cleaver SE. 1998. Rigor contractions in rested and partially exercised chinook salmon white muscle as affected by temperature. J Food Sci 63 (1):53-56.

Jerret AR, Stevens J, Holland AJ. 1996. Tensile properties in rested and exhausted chinook salmon (Oncorhynchus tshawytscha). J. Food Sci. 62, 527-532.

Jittinandana S, Kenney PB, Slider SD, Mazik P, Bebak-williams J, Hankins JA. 2003. Effect of fish attributes and handling stress on quality smoked arctic char fillets. J Food Sci 68: 57-63.

Johnston IA, Alderson R, Sandham C, Dinwall A, Mitchell D, Selkirk C, Nickell D, Baker R, Robertson B, Whyte D, and Springate J. 2000. Muscle fiber density in relation to the color and texture of smoked Atlantic salmon (Samo salar L.) Aquaculture 189:335-349.

Kestin SC, Warris PD. 2001. Farmed fish quality. Fishing News books, Cornwall, UK. pp 283-297.

Kiessling A, Espe M, Ruohonen K, Morkore T. 2004. Texture, gaping nd color of fresh and frozen Atlantic salmon flesh as affected by pre-slaughter iso-eugenol or $\mathrm{Co}_{2}$ anaesthesia. Aquaculture 236: 645-657.

Korhonen RW, Lanier TC, Geibrecht F. 1990. An evaluation of simple methods for following rigor development in fish. J. Food Sci. 55: 346-368. 
Kristoffersen S, Tobiassen T, Steinsund V, Oisen RI. 2006. Slaughter stress, post- mortem muscle pH and rigor development in Farmed Atlantic cod (Gadmus morhus L.) International Journal of Food Science and Technology 41:861-864.

Lave'ty J. 1984. Gaping in farmed salmon and trout. Torry Advisory Note 90. Aberdeen.

Lefevre F. 1997. Prorietes thermogelifiantes des myofbrillles et texture de la chair de truite. These. University Blaise Pascal, No:911.

Love RM. 1970. In: The Chemical Biology of Fisheries. Academic Press. London: 547 p.

Love RM, Lavety J, and Garcia NG. 1972. The connective tissue of fish VI. Mechanical studies on isolated myocomata. J Food Technology 7: 291-301.

Love RM. 1983. Texture and fragility of fish muscle cells. J. Texture Studies. 14:323-352.

Love RM, and Robertson I. 1968. The connective tissues of fish I. The influence of biological condition in cod on gaping in frozen-thawed muscle. J Food Technol 3:215-221.

Love RM, 1988. Food fishes- their intrinsic variation and practical implication London, UK: Farrand Press. p 179-180.

Lowe T, Ryder JM, Carrager JF, Wells RMG. 1993. Flesh quality in snapper, Pagrus auratus, affected by capture stress. J. Food Sci 58: 770-773,796.

Marx H, Brunner B, Weinzierl W, Hoffmann R, Stolle A. 1997. Methods of stunning freshwater fish: impact on meat quality and aspects of animal welfare. Z Lebensm Unters Forsch A 204:282-6.

Mazeaud MM, Mazeaud F. 1981. Adrenergic responses to stress in fish. In: Pickering AD, editor. Stress and fish. New York: Academic press Inc. p 65-67.

Moberg GP. 2000. The biology of animal stress: basic principles and implications for animal welfare. Biological Response to Stress: Implications for Animal Welfare GP Stress Research Unit, Department of Animal Science, University of California, Davis, California, USA. Pp.1

Mochizuki S, Sato A. 1994. Effects of various killing procedures and storage temperatures on postmortem changes in the muscle of horse mackerel. Nippon

Suisan Gakk 60:125-30.

Molinero A, Gonzalez J. 1995. Comparative effects of MS 222 and 2-phenoxyethanol on gilthead sea bream (Sparus aurata L.) during confinement. Comp. Biochem. Physiol.11lA3:405-414. 
Montero P, Borderias J. 1989. Distribution and hardness of muscle connective tissue in hake (Merluccius merluccius L). and trout (Salmo irideus Gibb). Zeitschrift Fur LebensmittelUntersuchung und-Forschung189:530-533.

Montero P, Borderias J. 1990. Distribution and hardness of muscle connective tissue in hake (Merluccius merluccius L.) and trout (Salmon irideus Gibb.). Z.Lebensm. Unters.-Forsch. 198:530-533.

Montero P, Mackie I M. 1992. Changes in intramuscular collagen of cod (Gadus morhua) during post-mortem storage in ice. Journal of the Science of Food and Agriculture. 59: 89-96.

Morkore T, Mazo PI, Tahirovic V, Einen O. 2008. Impact of starvation and handling stress on rigor development and quality of Atlantic salmon (Salmon salar L.). Aquaculture, 277 (3-4): 231238.

Morkore T, Rorvik KA. 2001. Seasonal variation in quality characteristics within and between age classes of farmed Atlantic salmon (Samo salar). In: Kestin SC, Warris PD. Farmed fish quality. Fishing new books. Blackwell science. Oxford. UK, p. 388.

Morkore T, Vallet JL, Cardinal M, Gomez-Guillen MC, Montero P, Torrissen OJ, Nordtvedt R, Sigurgisladottir S, Thomassen MS. 2001. Fat content and fillet shape of Atlantic salmon: relevance for processing yield and quality of raw and smoked products. J Food Sci 66:1348-54.

Nakayama T, Da-Jia L, Ooi A. 1992. Tension changes of stressed and unstressed carp muscle isometric rigor contraction and resolution. Nippon Suisan Gakkaishi. 58: 1517-1522.

Nakayama T, Goto E, Ooi A. 1996. Observation of characteristics muscle structure related to delay in red sea-bream rigor mortis by spinal cord destruction. Fish Sci 62 (6):977-984.

Ostrander J, Martinsen C, Liston J, McCullough J. 1976. Sensory testing of pen-reared Salmon and Trout. Journal of food Science 41:386-90.

Papinaho PA, Flecther DL, Buhr RJ. 1995. Effect of stunning amperage and peri-mortem struggle on broiler breast rigor development and meat quality. Poultry Sci 74(9):1533-1539.

Pate EF, Brokaw CJ. 1980. Cross-bridge behavior in rigor muscle. Biophys Struct Mech 7(1):51-63.

Pawar SS, Magar NG. 1965. Biochemical changes in catfish, tilapia and mrigal fish during rigor mortis. J. Food Sci 30: 121-125.

Pickering AD, Stewart A. 1984. Acclimation of the interregnal tissue of the brown trout, (Salmo trutta L.) to chronic crowding stress. J Fish Biol. 24: 731-740. 
Poli BM, Parisi G, Zampacavallo G, Scappini P, de Francesco M. 2003. The effect of slaughter methods on European sea bass (Dicentrarchus labrax) behaviour, rigor onset, plasmatic and tissue stress indexes and quality. Proceedings of the "First Joint Trans-Atlantic Fisheries Technology Conference (TAFT)”. 33rd and 48th Atlantic Fisheries Technology Conference. 11-14 June 2003, Reykjavik, Iceland.

Robb DHF, Kestin SC \& Warriss PD. 2000. Muscle activity at slaughter: I. Changes in flesh color and gaping in rainbow trout. Aquaculture, 182: 261-269.

Robb DHF, Kestin SC. 2002. Methods used to kill fish: field observations and literature reviewed. Animal Welfare: 11:269-282.

Robb D, Warriss P. 1997. How killing methods affect salmonid quality. Fish Farmer Nov/Dec: 48-9.

Robertson L, Thomas P. Arnold CR. 1988. Plasma cortisol and secondary stress responses of cultured red drum (Sciuenopsocellarus) to several transportation procedures. Aquaculrure. 68: I I 5 -I 30.

Rora AMB, Kvale A, Morkore T, Rorvik K-A, Stien SH, Thomassen MS. 1998. Process yield, color and sensory quality of smoked Atlantic salmon (Salmo salar) in relation to raw material characteristics. Food Res Int 31:601-9.

Roth B, Moller D, Veland JO, Imsland A, Slinde E. 2002.The effect of stunning methods on rigor mortis and texture properties of Atlantic salmon (Salmo salar). Journal of Food Science 67:1462-1466.

Roth B, Slinde E, Arildse J. 2006. Pre-or Post-mortem muscle activity in Atlantic salmon (Salmo salar). The effect on rigor mortis and the physical properties of fish. Aquaculture 257:504-510.

Ruff N, FitzGerald RD, Cross TF, Teurtrie G, Kerry JP. 2002. Slaughtering method and dietary $\alpha-$ tocopheryl acetate supplementation affect rigor mortis and fillet shelf-life of turbot Scophthalmus maximus L. Aquaculture Research, 33 (9):703-714.

Saito T, Ami K, Matsuyoshi M. 1959. A new method for estimating the freshness of fish. Bull. Jpn. SOC. Sci. Fish. 24:749-750.

Sato K, Yoshinaka R, Sato M, Shimizu Y. 1986. Collagen content in the muscle of fishes in association with their swimming movement and meat texture. Bull Jpn Soc Sci Fish 52:15951600 .

Schere K, Augusti PR, Steireas C, Bochi VC, Hecktheuer LH, Lazzari R, Radunz Neto J, Pomblum SOG, Emaqnuelli T. 2005. Effect of slaughter method on postmortem changes of grass carp (Ctenophoryngodon idella) stored in ice. J Food Sci 70: C348 - C353. 
Selye H. 1956. The Stress of Life. McGraw-Hill. New York: N.Y

Seki N, Tsuchiya H. 1991. Extensive changes during storage in carp myofibrillar proteins in relation to fragmentation. Nippon Suisan Gakk 57:927-33.

Sheehan EM, O’ Conner T P, Sheehy PJA, Buckley DJ, FitzGerald R. 1996. Effects of dietary fat intake on the quality of raw and smoked salmon. Irish $\mathrm{J}$ Agricultural and Food Research 35: 37-42.

Skervold PO, Fjaera SO, Christioffersen K. 1996. Pre-mortal chilling of farmed salmon (Salmon salar). Presented at: Refrigeration and Aquaculture, International Institute of Refrigeration, Commission $\mathrm{C}_{2}$ meeting, Bordeaux, March 20-22, 1996. International Institute of Refrigeration, Paris, France Conference proceedings, 167-173.

Skjervold PO, Fjaera SO, Oestby PB, Einen O. 2001. Live-chilling and crowding stress before slaughter of Atlantic salmon (Salmo salar). Aquaculture 192: 265-280.

Skjervold PO, Rora MB, Fjaera SO, Vegusdal A, Vorre A, Einen O. 2001a. Effects of pre-in-, or postrigor filleting of live chilled Atlantic salmon. Aquaculture 194:315-326.

Skjervold PO, Fjaera, SO, Ostby PB, Isaksson T, Einen O, Taylor R. 2001b. Properties of salmon flesh from different locations on pre- and post-rigor fillets. Aquaculture, 201:91-106.

Skrede G, Storebakken T. 1986. Instrumental color analysis of farmed and wild Atlantic salmon when raw, baked and smoked Aquaculture, 53:279-286

Sigholt T, Erikson U, Rustad T, Johansen S, Nordtvedt TS, Seland A. 1997. Handling stress and storage temperature affects meat quality of farmed-raised Atlantic salmon Salmo salar. J. Food Sci. 62 (4): 898-905.

Sigurgisladottir S, Hafsteinsson H, Jonsson A, Lie O, Nortvedt R, Thomassen MS, Torrissen O. 1999. Textural properties of raw salmon fillets as related to sampling method. J Food Sci 64(1):99_ 104.

Sikorski ZE. 1989. Chilling of fresh fish. In: Sikorski ZE. (Ed.), Seafood, resources, nutrional compostion and preservation. CRC Press, Inc. Boca Raton Florida. , pp. 93-111.

Silva JL, Harkness E, White TD. 1993. Residual effect of CO2 on bacterial counts and surface pH of channel catfish. J Food Prot 56: 1051-1053.

Sorensen NK, Brataas R, Nyvold TE, Lauritzen K. 1997. Influence of early proceeding (pre-rigor) on fish quality. In: Luten J. B. Borresen T, Oehlenschlaeger, J. Editors Seafoods from producer to consumer, integrated approach to quality. Amsterdam: Elsevier. p 253-263. 
Stien LH, Hirmas E, Bjornevik M,. Karisen O, Nortvedt R, Rora AMB Sunde J, Kiessling A. 2005. The effects of stress and storage temperature on the color and texture of pre-rigor filleted cod (Gadus morhua lL.) Aquaculture Res 36:1197-1206.

Surette ME, Gill TA, Blanc PJ. 1988. Biochemical basis of postmortem nucleotide catabolism in cod (Gadus morhua) and its relationship to spoilage. J. Agric. Food Chem. 36:19-22.

Thomas PM, Pankhurst NW, and Bremner HA. 1999. The effect of stress and exercise on post mortem biochemistry of Altantic salmon and rainbow trout. Journal of fish biology. 54:1177-1196.

Toyohara H, and Shimizu Y. 1988. Relation of the rigor mortis of the fifh body and the texture of the muscle. Nippon Sulsan Gakkaishi 54: 1795-1798.

Veland JO, Torresen O J. 1999. The texture of Atlantic salmon (Salmo salar) muscle as measured instrumentally using TPA and Warner - Brazler shear test. J Sci Food Agric. 79: 1737 -1746.

Watabe S, Kamal M, Hashimoto K. 1991. Postmortem hanges in ATP, creatinine phosphate,and lactate in sardine muscle. J. Food Sci. 56:151-153.

Whittle KJ. 1996. Factors affecting the quality of salmon (Salmon salar). Presented at: Refrigeration and Aquaculture, International Institute of Refrigeration, Commission C2 Meeting, Bordeaux, March 20-22, 1996. International Institute of Refrigeration, Paris, France. Conference Proceedings. p175-188.

Wood CM. 1992. Acid-base and ion balance, metabolism, and their interactions, after exhaustive exercise in fish. Journal of Experimental Biology 160: 285-308.

Yamada K, Harada K, Kawahara T, Itoh R, Tsukamoto S. 1983. J shimonoseki Univ fish. 31: 59-64.

Yamanoue M, Takahashi K. 1988. Effects of paratromyosin on increase in sarcomere length of rigorshortened skeletal muscles. J Biochem 103:843-7. 


\section{Introduction}

High demand for fish protein to nourish the growing human population has brought about increased Aquaculture production. The United States is reported to have the third largest seafoods consumers in the world. Asian and Pacific countries aquaculture production in 2008 were 89 percent volume and 79 percent by value (FAO, 2010). West Virginia is one of the seafood producing states in the United States, especially in Trout production. It was estimated that the value of trout produced in West Virginia in 2009 was more than \$2 million (Semmens 2010). Hence, farmed Salmonid has captured a majority of the market in quantity and quality. Enhancing fish quality is of utmost concern to the aquaculture industry. Increasing in quantity and quality of fish is essential in maintaining steady flow between producers and consumers. Fish quality enhancement is directly linked with antemortem handling and postmortem biochemical processes, which is greatly impacted by changes in postmortem metabolism directly affected by harvesting, handling, and processing protocols. Other factors are physiological conditions of fish muscle before harvest, fish species, $\mathrm{pH}$ of the muscle, water temperature after death (Wall, 2001), and time of filleting, (Skjervold and others 1999). (Ozogul and Ozogul 2004; Sigholt and others 1997; and Urbieta and Gines 2000). Some of these factors have been reported to cause early onset of rigor mortis leading to changes in fillet quality (Sato and others 1991)

Rigor mortis is one of the salient postmortem changes in muscle taking place immediately after death with a major effect on appearance and structure. FAO reported that rigor mortis is as a result of chemical changes in fish after death. Bito and others (1983) concluded that rigor mortis development varies from species to species.

Onset of rigor (first described by Ewart 1887; Benson 1928) and duration of rigor is said to be dependent on the glycogen-ATP relationships (Hamm 1981). Rigor in fish starts from the tail up to the 
head until the whole body is stiff and later flaccid (post rigor stage). After a fish has died, calcium ions leak into the muscles, causing them to contract. Adenosine triphoshate (ATP), the biochemical energy carrier that provides energy to relax the muscle again, is no longer present, so the muscles become rigid. This locking of the muscles, called rigor mortis, can be slowed down by chilling the fish immediately after death and minimizing perimortem struggle. Muscle contraction depends on the $\mathrm{pH}$ of the fish and temperature at which they were kept after filleting operations. (Dunajski 1979)

Several studies have reported the development of rigor mortis closely connected to texture. Stien and others (2005) observed that pre-rigor fillets of Atlantic salmon (Salmo salar) are superior to post-rigor fillets in terms of firmer texture and better color. Texture is an important factor that determines quality of raw fish and consumers' preference. It is generally assumed that fish muscle is more tenderer than chicken and Mammalian muscle (Ando and others 1991). Tenderization is said to be caused by the weakening of Z-disc structure of myofibril with storage time (Hatae and others 1985) depending on the species (Ando and others 1991). Also, difference in the hierarchical arrangement of fish muscle influences differences in texture between terrestrial species and teleost fish.

In addition, Ando and others (1991) found an increased in breaking strength because of an increased rigor index. It has been observed that Atlantic salmon, Atlantic cod, rainbow trout (Salmo gairdneri) carp and parrot bass are classified as fish fillets with tough texture at pre-rigor state and less firm texture deep-rigor and post-rigor stage (Sorensen and others 1997; Ando and others 1991). However, there is no report on the effect of rigor on rainbow trout fillet texture. To enhance our understanding of how rigor state at processing affects fillet quality, the present study evaluates the effects of postharvest processing time on quality of rainbow trout fillets. 


\section{Materials and Methods}

\section{Experimental Fish}

Four inch fingerling rainbow trout (Oncorhynchus mykiss) Case Western temperature tolerant strain were stocked at Dogwood Lakes in Morgantown, WV. Fish were harvested at 2 years of age during May-June 2010. Forth-five rainbow trout were used for this study; 15 fish were sampled on each of 3 separate days. All trout were immediately percussively stunned and placed in a cooler containing crushed ice. Fish were delivered to the West Virginia University, Meats Laboratory in Morgantown within 30-45 minutes of harvest. Upon arrival, fish were gutted and each individual fish was weighed and tagged; whole body weight, length, and rigor angle were measured and fish were randomly divided into 3 groups of 5 fish each for 3 processing treatments; 0 h, $24 \mathrm{~h}$, and $48 \mathrm{~h}$ postharvest. At zero h post-harvest (upon arrival to the meats lab), five fish (pre-rigor) were immediately gutted, hand filleted to generate a butterfly fillet, and skinned for separable muscle determination. A sample was removed and frozen in liquid $\mathrm{N}_{2}$ for K-value measurement; an additional ( $\left.\sim 5 \mathrm{~g}\right)$ sample was excised for sarcomere length measurement. The alternate side was aerobically packaged (PVC film) and stored at $3^{\circ} \mathrm{C}$ for $48 \mathrm{~h}$ post-harvest; at this time, fillets were sampled for sarcomere length, and K-value. Sample was also taken for cooking and subsequent texture measurement. The remaining 10 fish were packed in crushed ice for 24 (deep-rigor) and 48 h postharvest (post-rigor) sampling; rigor angle was continuously monitored from harvest. At 24 and 48 h postharvest, fish were randomly removed from crushed ice, and sampled as described for $0 \mathrm{~h}$ post-harvest fish. At $48 \mathrm{~h}$, a fillet from each of the processing treatments was vacuum packed (Ultravac, Model UV500, Koch; Kansas City, $\mathrm{MO})$, and frozen at $-20^{\circ} \mathrm{C}$ for proximate analyses. 


\section{Sample Measurements}

Several fillet attributes were measured at processing. Head-on gutted (HOG), butterfly fillet weight, boneless skinless fillet weight (separable muscle) and length, and belly flat thickness (cranial, middle, and caudal) were measured. Percentage HOG weight was calculated as = HOG / whole body weight $(\mathrm{WBW}) * 100$; condition factor was calculated as $\mathrm{CF}=100 \times\left(\mathrm{BW} \times 1^{-3}\right)$.

\section{Fillet $\mathrm{pH}$}

Fillets pH were measured with pH meter (pH/ion analyzer 350 (Corning Inc., Corning, N.Y., U.S.A.) calibrated at $\mathrm{pH} 4.0$ and 7.0 and equipped with a surface electrode. The $\mathrm{pH}$ values were recorded immediately by inserting probes into the dorsal part of the fillet at each processing time. Frequent cleaning of the electrode was very important for consistent results.

\section{Rigor angle}

The rigor state of each fish was determined by measuring the rigor angle as described by Korhonen and others (1990) and revised by Lowe and others (1993). Rigor angle was measured as progressive stiffening of the fish; fish were placed on a table and the body, caudal to the pectoral girdle, was allowed to hang over the table edge as rigor progressed. The angle formed with the table top became smaller as muscle stiffening, and thus rigor, progressed. Rigor angle was measured on the sampled fish placed on their right and left side at $0,3,6,24,27,36$, and 48. Angle was determined using a protractor and the angle of both measurements is reported.

\section{Color measurement}

Raw fillet color $\left(\mathrm{L}^{*}, \mathrm{a}^{*}, \mathrm{~b}^{*}\right)$ was determined using a Minolta chroma-meter CR-300 ${ }^{3}$, (Minolta; Osaka, Japan) calibrated to a white standard. For fillets color determination, measurements were made 
directly on the fillets using the $\mathrm{D}$ light source. $\mathrm{L}^{*}$ describes the lightness of the sample, $\mathrm{a}^{*}$ represents redness $\left(\mathrm{a}^{*}>0\right)$ and $\mathrm{b} *$ indicates yellowness $(\mathrm{b} *>0)$.

\section{Proximate Analyses}

Fish fillets were subdivided into small pieces, and these pieces were frozen in liquid nitrogen and powdered in a Waring commercial blender (Model 51BL31) for 2-3 min. Each powdered sample was subdivided into two whirl pak ${ }^{\circledR}$ bags and stored at $-10^{\circ} \mathrm{C}$ until proximate analyses. Proximate composition (moisture, crude fat, crude protein, and ash) was determined using standard methods of the Association of Official Analytical Chemists (AOAC, 1990). Measurements were performed in duplicate and averaged for data analyses.

Moisture. Approximately one gram of each powdered sample was weighed and placed in a preweighed aluminum pan. Samples were dried in an oven (STABIL Thermo Gravity oven, Blue M Electric Company, Blue Island Illinois, USA) at $110^{\circ} \mathrm{C}$ for 24 h to a constant weight. Samples and pans were cooled in desiccators and re-weighed. Moisture content was calculated as the percent weight loss after drying.

Crude Fat. Crude fat was extracted from fillet samples using the Soxhlet indirect method. A 1-1.5 gram sample was weighed into filter paper; filter paper and sample were placed in a Soxhlet extractor; and crude fat was separated with petroleum ether for 18-20 h. Extracted samples were subsequently dried overnight at $110^{\circ} \mathrm{C}$ and weighed to determine crude fat content.

$\%$ Crude Fat $=\left[\left(\mathrm{W}_{3}-\mathrm{W}_{2}\right)-\mathrm{W}_{1} \div \mathrm{W}_{3} \times 100\right]$

- $\mathrm{W}_{1}=$ grams of moisture per sample

- $\mathrm{W}_{2}=$ weight of dry in grams 
- $\mathrm{W}_{3}=$ weight of wet sample in grams

Crude Protein. Crude protein was determined using kjeldahl N determined by the Ljeltectm 2300 (Foss North Americans; Eden Prairie, Minnesota, U.S.A.). Half gram samples were weighed accurately on a filter paper and 30mg copper-sulfate tablets (used as a catalyst) were both transferred to the flask. $10 \mathrm{ml}$ of sulfuric acid $\left(\mathrm{H}_{2} \mathrm{SO} 4\right)$ were added, dissolved by swirling the flask. Samples were heated in a $400^{\circ} \mathrm{C}$ heating block, equipped with an exhaust manifold for approximately $1.5 \mathrm{~h}$ to accomplish digestion. After cooling, 25ml of distilled water was cautiously added with swirling and heating to re-suspend solids. Tubes containing the solutions were distilled on the Kjeldal machine for titration. Millimeters of acid required to titrate the sample was then used to determine nitrogen content. Nitrogen is finally converted to crude protein by multiplying by $6 \cdot 25$.

Ash Content. Ash content was estimated in duplicate by burning approximate $1 \mathrm{~g}$ samples in a type A1500 muffle furnace (F-A1525M-1; Thermocline Corporation; Dubuque, IOWA, USA) overnight at $500^{\circ} \mathrm{C}$; ash was weighed after cooling and expressed as a percent of the raw weight.

\section{Percent fillet shortening, myotome length, and fillet temperature}

Percent fillet shortening was calculated as $100-\mathrm{X}$, where $\mathrm{X}=48 \mathrm{hr}$ length $/$ ohr length $\times 100$. The length of the myotome was measured from one myoseptum to an adjacent myoseptum, perpendicular to the myosepta on either side of the myotome. Myotomes were measured with calipers at two sites (the connective tissue layer/myotome) and the average of the two sites was recorded. Fillet temperature was measured at the cranial portion of the dorsal musculature with a digital thermometer 
probe (Model 9800, Type K thermocouple, Taylor Scientific Instruments, Arden, N.C., USA); temperature was determined when $\mathrm{pH}$ was measured.

\section{Sarcomere length}

Sarcomere length was measured as described by Koolmees and others (1986). Three solutions were prepared as a fixative; Solution A consisted of $0.1 \mathrm{M} \mathrm{NaHPO}_{4}$, buffered to $\mathrm{pH} 7.2$; Solution B consisted of $200 \mathrm{ml}$ of 5\% Glutaraldehyde brought to 1 liter with $0.1 \mathrm{M}$ NaHPO4 buffer at $\mathrm{pH}$ 7.2; and Solution C consisted of 68.46g/liter of $0.2 \mathrm{M}$ sucrose, with $0.1 \mathrm{M}$ NaHPO4 buffered to $\mathrm{pH}$ 7.2. All solutions were stored at $4^{\circ} \mathrm{C}$.

Sample Preparation. Samples were collected from the white muscle in an area ventral to the dorsal fin. Fillet tissues, excised $0 \mathrm{~h}$ postharvest (pre-rigor), $24 \mathrm{~h}$ postharvest (deep-rigor), and $48 \mathrm{~h}$ postharvest (post-rigor) were divided into small pieces $(3.0 \times 3.0 \times 2.0 \mathrm{~cm})$ longitudinal to the muscle fiber orientation. The remaining fillets from 0 and $24 \mathrm{~h}$ post-harvest processing treatments were stored at $3.3^{\circ} \mathrm{C}$ until $48 \mathrm{~h}$ post-harvest for sarcomere length determination. Samples were placed in vials, and solution B was added for fixation at $4^{\circ} \mathrm{C}$ for $4 \mathrm{~h}$. Then, the glutaraldehyde solution was poured off and replaced with solution C. Samples were held at $4^{\circ} \mathrm{C}$ for up to 7 days in solution C. Sarcomere length was determined using light microscopy (Nikon Eclipse E600 120v, 2.4A), according to the procedure of Cross and others (1981) with slight modification. Samples were viewed in a microscope. A drop of sample was transferred to the glass slide and a cover slip was place over the sample. The slide was examined under the microscope at $100(0.5 \mathrm{~m})$ magnification for the number and length of myofibrils. Sarcomere length were measured and photographed with a camera (camera model, Nikon digital 
dxm1200; No 12928; size-338 bytes, version-ACT 1Ver2, Photoshop CS software). Five to ten sarcomere measurements were taken for each fillet.

\section{Texture Analysis}

At $48 \mathrm{~h}$ post-harvest, a fillet section $(8 \mathrm{~cm} \times 4 \mathrm{~cm})$ was removed from each of 15 left and 15 right sides. Fillet sections were weighed and cooked to $65.5^{\circ} \mathrm{C}$ in a microprocessor- controlled oven (Model CVU-490; Enviro-pak, Clackamas, Oreg., USA); these sections were tempered to room temperature before re-weighing. Cooked fillets were used to determine \% cook loss as follows: 100 \% cook yield, where CY= Weight of cook section/ Weight of raw section $\times 100$ and shear force.

Allo-Kramer (AK) Texture. Texture measurements were conducted according to the method of Aussanasuwannakul and others (2010). A force - deformation curve was generated, using a 5-blade, Allo-Kramer shear force cell and a variable blade shear device attached to a Texture Analyzer (TA-HDi; Texture Technologies Corp., Scarsdale, NY, U.S.A). A 50kg load cell was used, and sample was sheared at a speed of 127mm/min. Texture Expert Exceed, Ver. 2.60 software from Stable Micro Systems Ltd., (Surrey, UK) was used to process acquired shear data.

Variable-blade (VB) Texture. Cooked fillet samples were placed on a flat base (plastic cutting board) and sample orientation was adjusted to align with the blade area of the VB attachment (30 X $80 \mathrm{~mm}$ ). Variable shear blade orientation was the same as in AK evaluations; except that the attachment was set to return to its origin before the blade touched the base. In each case, samples were sheared perpendicular to the orientation of the fillet musculature.

The force-deformation curve of each sample was recorded. Peak shear force was recorded, and total energy to peak force were calculated and expressed as $\mathrm{g} \times \mathrm{mm}$. 


\section{K-value}

Samples were collected at the same time as those collected for sarcomere length determination. These samples were frozen in liquid $\mathrm{N}_{2}$ and stored at $26.6^{\circ} \mathrm{C}$ until $\mathrm{K}$-value was measured. ATP catabolites were determined using high performance liquid chromatography (HPLC) according to Sellevold and others (1986) with a few modifications. For sample from each rigor state, one gram of tissue was homogenized with $5 \mathrm{ml}$ of ice-cold, $0.4 \mathrm{M}$ perchloric acid for 20s; the homogenate was filtered through Whatman \#41 filter paper. Filtrate $(600 \mu \mathrm{l})$ was neutralized by the addition of ice-cold $\mathrm{K}_{2} \mathrm{CO}_{3}(330 \mu l$, $0.36 \mathrm{M})$.

ATP (Adenosine triphosphate), ADP (Adenosine diphosphate), AMP (Adenosine monophosphate), IMP (inosine mono phosphate), INO (Inosine), and Hx (hypoxanthine) were analyzed by High Performance Liquid Chromatography (HPLC; system Water ${ }^{\mathrm{TN}}$ ). The system

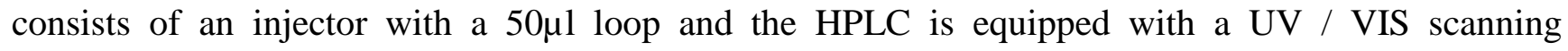
wavelength detector set at $254 \mathrm{~nm}$. Chromatograms were integrated with star software. The isocratic mobile phase, consisting of $0.04 \mathrm{M}$ monobasic potassium phosphate and $0.06 \mathrm{M}$ dibasic potassium phosphate, was filtered through $0.45 \mu \mathrm{m}$ filter. Separations were achieved on a Supelcosil column LC18-T $(250 \times 4.6 \mathrm{~mm})$ and guard column kit. Flow rate was $1.2 \mathrm{ml} / \mathrm{min}$ and run time was $45 \mathrm{~min}$. Sigma external standards of the ATP metabolites and degradation products (ATP, ADP, AMP, IMP, INO, and Hx) were compared with the sample profiles.

\section{Statistical analysis}

This experiment was conducted in the context of a randomized complete block design with a random block effect (DAY). For fillet quality data, treatment (fixed) effect was time of process (0, 24, and 48 h postharvest). Data were analyzed by analysis of variance (ANOVA) using the Mixed Model 
(MIXED) procedure of SAS ${ }^{\circledR}$ system for Windows, version 9.1 (SAS Institute Inc., 2004), to establish treatment effects. Means and standard errors were generally shown. Significant effects defined at $\mathrm{P} \leq$ 0.05 .

\section{RESULTS AND DISCUSSION}

\section{Weight and Length}

Condition factors, length, head-on-gutted weight, percent HOG weight, whole body weight, percent butterfly fillet, percent separable muscle, and average belly fat were not affected $(\mathrm{P}>0.05)$ by storage time (Table 1). However, the average values of all processing data, except percent separable muscle, percent head-on gutted weight, and percent butterfly fillet weight tended to decrease from 0 to $48 \mathrm{~h}$ postharvest. Condition factor of rainbow trout at 0 (1.23 \pm 0.03$)$, and $24 \mathrm{~h}$ postharvest $(1.21 \pm$ $0.03)$ was greater than at $48 \mathrm{~h}$ postharvest $(1.20 \pm 0.03)$. This condition factor indicated that fish were well nourished, had good biological condition, and had sufficient access to feed before harvest. Whole body weight at $0 \mathrm{~h}$ postharvest $(929.56 \pm 8.84 \mathrm{~g})$ decreased to $(840.08 \pm 38.84 \mathrm{~g})$ at $24 \mathrm{~h}$ postharvest and $(871.73 \pm 38.84 \mathrm{~g})$ at $48 \mathrm{~h}$ postharvest stage. Head on gutted weights at $0 \mathrm{~h}$ postharvest $(813.18 \pm$ $30.38 \mathrm{~g})$ decreased to $(735.24 \pm 30.38 \mathrm{~g})$ at $24 \mathrm{~h}$ postharvest and $(761.79 \pm 30.38 \mathrm{~g})$ at $48 \mathrm{~h}$ postharvest. Percentage of head-on-gutted weights remained constant at $87 \%$ from 0 to 24 h postharvest.

Percentage of head-on-gutted weight increased slightly $(\mathrm{P}>0.05)$ from 0 to $48 \mathrm{~h}$ postharvest. Butterfly fillets weights were higher after $24 \mathrm{~h}$. Slight changes in butterfly weight at different stages showed the possibility of shrinkage that may have been associated with the absence of muscle restraint for boneless, skinless fillets as earlier reported by (Einen and others 2002; Sorensen and others 1997). Average belly fat steadily declined throughout the course of the study. This constant HOG weight suggests that variation in WBW was due to variation in visceral weight. Variation in viscera weight 
may be associated with differences in the amount of visceral fat as well as gastrointestinal tract content.

Gutted fish (24-48 h postharvest) did not experience any changes during ice-storage before processing. Separable muscle yield at $0 \mathrm{~h}$ postharvest was low (47\%); whereas, the $48 \mathrm{~h}$ postharvest, separable muscle yields were slightly higher (48\%) as stated in table 1 . This observation indicates that a low weight at $0 \mathrm{~h}$ postharvest could be the result of drip losses. Kristoffersen and others (2006a) previously observed similar results in cod. During rigor development, overall weight and length of whole fish did not change, but slight changes occur in fillet weight. To conclude this section, time of processing, postharvest, did not affect $(\mathrm{P}>0.05)$ processing attributes.

\section{Fillet pH}

To monitor postmortem metabolic changes, as assessments of rigor development and $\mathrm{pH}$ decline are important to consider. The present study reports the effect of processing time on rigor development, and muscle $\mathrm{pH}$ decline in rainbow trout (Oncorhynchus mykiss; Fig 1.). Postharvest processing and storage time affected fillet $\mathrm{pH}$. Variations in $\mathrm{pH}$ value (6.50-6.84) are reasonable since values fall in the normal range for salmonids. The 0 -h $\mathrm{pH}$ value decrease from $\mathrm{pH} 6.84$ to $\mathrm{pH} 6.50$ at about 20-24 h postharvest; $\mathrm{pH}$ subsequently increased to $\mathrm{pH} 6.69$ at 48 h postharvest. The 0-h $\mathrm{pH}$ value falls within the range of other fish species such as European sea bass (pH 6.8) and Atlantic salmon (pH 6.7). Robb and others (2000) reported similar declines in postmortem pH for rainbow trout anaesthetized before slaughtering. Will and others (2006) reported that initial $\mathrm{pH}$ of rainbow trout fillets stunned with $\mathrm{N}_{2}$ and percussion was 6.88 and 7.2, respectively. Fish from the current study were percussively stunned with minimal perimortem struggle. Fillet $\mathrm{pH}(\mathrm{P}<0.05)$ decreased during rigor development in agreement with Sen (2005); this author observed a high $\mathrm{pH}$ after death, a low pH 
at the beginning of rigor, and a slightly elevated $\mathrm{pH}$ when resolution began at $0^{\circ} \mathrm{C}$. These data suggest that fish were handled with minimum stress during harvest that, coupled with percussive stunning, would slow the biochemical reactions in fish fillets by minimizing perimortem struggle.

Values at different times postmortem correspond with previous reports; a $\mathrm{pH}$ of 6.3 was observed in post-rigor (Loughna \& Goldspink 1985; Abe \& Okuma 1991; Durran and others 2008), mirror carp and rainbow trout muscle; Erikson \& Missimi (2008); Einen and others (2002) reported a $\mathrm{pH}$ of 6.6 in pre-rigor salmon fillets. The decline in muscle $\mathrm{pH}$ of rainbow trout during rigor development is similar to the trend of rested-harvest, catfish muscle $\mathrm{pH}$ at 1, 12, and 24h. In agreement with this present study, Bosworth and others (2004) reported a muscle pH of 6.8 for low-water stressed catfish immediately after slaughtering to be similar to the muscle $\mathrm{pH}$ of rainbow trout muscle at slaughter. The drop in $\mathrm{pH}$ during rigor development in postharvest fillets is caused by conversion of glycogen to lactate during postmortem (glycolysis) metabolism. Love (1988); Skjervold and others (2001); Stien and others (2005); Sikorski and others (1990) suggested the decrease in pH at $24 \mathrm{~h}$ followed by an increase by $48 \mathrm{~h}$ was associated with endogenous and bacterial enzymes generating nitrogenous compounds with basic properties. The 24-h pH is typical of rainbow trout fillets at this stage of post mortem metabolism. In conclusion, the higher 0-h $\mathrm{pH}$ corresponds to low lactic acid accumulation at this point.

\section{Rigor Angle}

The onset and development of rigor mortis influences appearance and structure of fish muscle (Berg and others 1997). As previously mentioned, rigor development is closely linked to changes in ATP and $\mathrm{pH}$ during postmortem metabolism in fish muscle. The result of postmortem biochemical processes in fish is rigor development (Watabe and others 1990). The stiffening that is 
characteristics of rigor mortis is due to permanent cross-bridges that form between the myofibrillar proteins, actin and myosin. Because this reaction takes place in muscles, connective tissues are affected. The cause of rigor development is the disappearance of ATP which in turn allows permanent cross bridges to form between actin and myosin; accumulation of lactic acid and a drop in muscle $\mathrm{pH}$ occurs concurrently with the development of rigor mortis (Bendall 1951; Erikson 2001; Poli and others 2003; Stien 2005).

The time course of rigor development in rainbow trout (Oncorhynchus mykiss) was assessed according to Korhonen and others (1990) and as revised by Lowe and others (1993). Results showed that storage time $\left(0,3,6,24,30\right.$, and $48 \mathrm{~h}$ at $\left.4^{\circ} \mathrm{C}\right)$ affected $(\mathrm{P} \leq 0.05)$ rigor development (Figure 2$)$. There was a rapid decline in rigor angle from 0-24 h as ATP was depleted and actomyosin formation occurred. Rigor angle had begun to drop by 3 h postharvest, reaching a minimum rigor angle by 24 h; some resolution had begun by $27 \mathrm{~h}$. By $48 \mathrm{~h}$, muscle had relaxed so that rigor angle had increased by approximately $24^{\circ}$. This finding is similar to observations of Roth and others (2006) in rainbow trout, Sorensen and others (1997); Stien and others (2005); and Poli and others (2003) in Atlantic salmon. Lowe and others (1993) indicated that rigor development and ATP depletion in snapper (Pagrus auratus) muscle were delayed in unstressed fish. Thomas and others (1999) reported that Atlantic salmon, carp, and rainbow trout reach maximum rigor at $24 \mathrm{~h}$ and that rigor are resolved after $24 \mathrm{~h}$. In the case of tilapia, Curran and others (1986) reported onset of rigor $2 \mathrm{~h}$ after harvest and storage at $0^{\circ} \mathrm{C}$; the time course for full rigor was variable, ranging from 8 to $27 \mathrm{~h}$, before resolution of rigor mortis (fillet flexibility) was achieved. Whereas, Kristoffersen and others (2006) reported that Atlantic cod (Gadus morhua L.) exhibited full rigor at approximately $48 \mathrm{~h}$ postmortem and that stressed cod reached full rigor after 20-24 h. Slow resolution occurred at 48 h following muscle energy depletion. 
These findings coincided with the observations of Abe and Okuma (1991) who concluded that Carp attained full rigor after $24 \mathrm{~h}$ on ice at $3^{\circ} \mathrm{C}$, which depends on the difference in sea and storage temperatures. When storage temperature is warmer than water temperature during production, the time of death to onset of rigor is short and vice versa if the storage temperature is cold, slowing postmortem metabolism. The use of percussive stunning, minimizing capture stress and perimortem struggle, may have reduced the rate of rigor development in the present study. Additionally, immediate storage on ice following percussive stunning would have lowered muscle temperature and thus slowed the postmortem, biochemical changes that precipitate rigor development.

\section{Color Measurements}

Color is perhaps the most important attribute affecting quality perception. Lauritzsen and others (2004) reported that reflectance of light from the fillets' surface at specific wavelength yields the instrumental color values. Processing time appears affect color; lightness ( $\left.\mathrm{L}^{*}\right)$, redness $\left(\mathrm{a}^{*}\right)$, and yellowness $\left(b^{*}\right)$ of rainbow trout fillets. The $a^{*}$ and $b^{*}$ values were highest $(\mathrm{P} \leq 0.05)$ at $0 \mathrm{~h}$ (Table 2$)$. The highest $\mathrm{L}^{*}$ values were observed for fillets generated at $48 \mathrm{~h}$ postharvest, and lightness did not differ $(\mathrm{P}>0.05)$ for fillets generated at 0 and $24 \mathrm{~h}$ postharvest. Fillets, at $48 \mathrm{~h}$, reflected less light (were more translucent) than those at 0 and $24 \mathrm{~h}$. Others have reported, for Atlantic salmon, that $\mathrm{L}^{*}$ values were significantly lower at 0 than at 48 h postharvest (Skjervold and others 2001a, b; Einen and others 2002). Stien and others (2005) concluded that fillets are usually less translucent soon after slaughter. Elvevoll and others (1996) observed a duller color in cod fillets at 0 than at $48 \mathrm{~h}$ postharvest. The impact of astaxanthin on fillet color is a function of the light-absorbing and -reflecting properties of the fillet (Kristoffersen and others 2006; Ozbay and others 2006) concluded that hydrophobically bound astaxanthin and the carotenoids are prone to light, heat, and oxygen in the white muscle of 
salmonids. In the current study and as indicated by a higher $\mathrm{L}^{*}$ value, fillets at $48 \mathrm{~h}$ postharvest had faded, compared to fillets generated at 0 and $24 \mathrm{~h}$ postharvest. The higher $\mathrm{L}^{*}$ value for fillets generated at $48 \mathrm{~h}$ may have been attributed in part to difference in sarcomere length (Figure 3); it is also likely that differences associated with exposure to air affected this color attribute. Minolta b* value was higher $(\mathrm{P} \leq 0.05)$ for $0 \mathrm{~h}$ fillets compared to 24 and $48 \mathrm{~h}$ postharvest fillets. Fillets $\mathrm{b}^{*}$ values at 24 and $48 \mathrm{~h}$ were not different $(\mathrm{P}>0.05)$.

Fillet a* was highest $(\mathrm{P} \leq 0.05)$ at $0 \mathrm{~h}$ postharvest compared to 24 and $48 \mathrm{~h}$ postharvest. Fillet $\mathrm{a}^{*}$ values were not different at 24 and $48 \mathrm{~h}$ postharvest. The rapid decrease in redness could be a result of rigor development and oxidative and autolytic changes from 0 to 24 and 48 h postharvest. A higher $\mathrm{a}^{*}$ and lower $\mathrm{L}^{*}$ value at $0 \mathrm{~h}$ postharvest stage is in agreement with previous research on Atlantic salmon (Skrede and Storebakken 1986). At 0 h postharvest for the current study, fillets were more red and yellow than fillets from 24 and 48 h groups. Little and others (1979) reported that differences in light scattering properties and cellular matrix will affect color perception. Changes in light reflection and fillet redness were influenced by rigor through its influence on the smoothness and structure of the fillet surface; fillet thickness may also be an important factor depending on rigor development (Skjervold and others 2001; Erikson and Misimi 2008). It is conceivable that fillet thickness could be affected by rigor development if fillets were removed pre-rigor and thus, lack skeletal restraint. Fillet shortening could result in fillet thickening.

Greater redness $\left(\mathrm{a}^{*}\right)$ and yellowness $\left(\mathrm{b}^{*}\right)$, observed for $0 \mathrm{~h}$ postharvest filleting, is a result of a fresher fillet condition. Differences in $\mathrm{pH}$ are likely responsibly for some of the variation in $\mathrm{L}^{*} \mathrm{a}^{*}$ and b* values observed in this study (Foegeding and others 1996). A higher $\mathrm{pH}$ at $0 \mathrm{~h}$ postharvest predisposes fillets to a tighter muscle structure and thus more light absorption. 


\section{Proximate analyses}

Raw samples. Moisture, crude fat, ash, and crude protein content of rainbow trout fillets are presented in Table 3. Lipid and moisture are basic components of fish composition (Jobling 1994), and the relative amounts of these constituents impact quality, Hamm (1981); Borderias and others (1983) concluded that a series of complex changes at the end of rigor resulted in fillets tenderness and $\mathrm{pH}$ decline, and these biochemical changes alters cell membrane permeability, permitting enzymes to degrade fillet proteins. Francesco and others (2004) observed fillet moisture content (72.87\%) similar to our 0 h fillets. Gokoglu and others (2004) and Duran and others (2008) have reported similar findings.

Fillets fat content was not affected by processing time postharvest. Tokur (2000, 2007); Gokoglu and others (2004) reported lower trout fillet fat content than observed in the present study (3.88\% and 3.44\% respectively). Francesco and others (2004) reported that fat content was higher at 0 and $24 \mathrm{~h}$ than at $48 \mathrm{~h}$ postharvest in several other salmonid species. Skjervold and others (2001) observed increased water and reduced fat content in all rigor groups during ice storage. In support of the aforementioned findings, the fish filleted at $48 \mathrm{~h}$ postharvest had lower fat content and higher water content than the other groups.

Protein content was higher $(\mathrm{P} \leq 0.05)$ at $0 \mathrm{~h}$, and decreased from $20.7 \%$ at 0 h to 20.2 and 20.0 $\%$ at 24 and 48 h postharvest, respectively. Ash content of muscle was higher $(\mathrm{P} \leq 0.05)$ when fish were processed at $0 \mathrm{~h}$ postharvest, and there appeared to be an inverse relationship between ash and moisture content. In general, an increase in water content likely diluted remaining constituents.

Cooked Samples. Cooking temperature and time are important factors affecting the final composition of cooked fish fillets. Cooked fillet composition is similar to findings of other researchers 
(Gokoglu and others 2004; Tokur 2007). A significant decrease in the moisture content and a concomitant increase in cook loss were observed (Table 4, $\mathrm{P} \leq 0.05$ ). Losses observed during cooking are due to dehydration of muscle and drainage of lipids and water from the muscle. Cook losses were $11.09 \pm 0.52,12.40 \pm 0.52$, and $12.43 \pm 0.52 \%$ for 0,24 , and $48 \mathrm{~h}$ processed fillets, respectively. These values are in the range reported by Howgate (1979). The moisture content of rainbow trout fillets produced at $0 \mathrm{~h}$ postharvest $(69.41 \%)$ was significantly higher than at $48 \mathrm{~h}$ postharvest (69.25\%). This response can at least partially be explained by the longer storage time for $48 \mathrm{~h}$ processed fish. This is due to structural changes within the protein bonds in the muscle during storage that adversely affects the cooked muscle's ability to retain moisture. Robb and others (2002) reported a similar trend in Atlantic salmon (Salmo salar). Additionally the higher $\mathrm{pH}$ of $0 \mathrm{~h}$ fillets may have enhanced the water binding ability of these proteins during texture development when cooked.

Moisture loss during ice storage of meat is due to the translocation of the water in muscle (Huff-Lonergan and Lonergan 2005). FAO reports (2001) stated that chilled fillets lose water slower than chilled whole fish during the rigor process. Also, changes in muscle $\mathrm{pH}$ result in changes in moisture content as rigor development progressed. Higher water content in $0 \mathrm{~h}$ postharvest fillets may be a result of higher $\mathrm{pH}$ value compared to lower water content of $48 \mathrm{~h}$ postharvest fillets. Lower $\mathrm{pH}$ value may have contributed to the observed lower water content due to protein denaturation. Connective tissue strength within the myofibril has been found to be lower at reduced pH (Love and others 1972).

Several reports have concluded that fat increased during smoking. However, fat content of the cooked sample is less than the fat content of the raw sample; perhaps cooking rendered fat from the product reducing fat content of the cooked fillet. Fat content of cooked fillets in this study was not 
affected by time of postharvest processing. Moisture content was highest at $0 \mathrm{~h}$ postharvest (69.41\%) followed by 24 (69.25\%), and 48 h postharvest (68.49\%). There appears to be a correlation between fat and moisture content in fish muscle. The decrease in the moisture content at different rigor states with an increase in fat content demonstrates the inverse correlation between moisture and lipid content in fish muscle that has been observed by other researchers (Exler 1987; Bligh and others 1988; Candela and others 1997; Morkore and others 2002). According to Haard (1992), moisture and fat content in salmonid muscle are generally inversely related.

Cook losses tended to increase with time postharvest; and they appeared to be related to reduced moisture content and an increased fat content. This observation is in agreement with Morkore and others (2001) who stated that percentage water loss from Atlantic salmon fillets increased, commensurate with an increase in cooked fat content. Similar reports were observed by GomezGuillen and others (2000) at $20^{\circ} \mathrm{C}$ for $2 \mathrm{~h}$ in $0 \mathrm{~h}$ postharvest Atlantic salmon (Salmon salar; Morkore and others 2001), at $100^{\circ} \mathrm{C}$ for 30 minutes and $80^{\circ} \mathrm{C}$ for 45 minutes in Tilapia (Yanar and others 2006). Park and others (1987) reported 6.9\% cooking loss at $90^{\circ} \mathrm{C}$ for $0 \mathrm{~h}$ postharvest beef versus $10.9 \%$ for $48 \mathrm{~h}$ postharvest beef. Ofstad and others (1993) indicated that protein (collagen) denatured at $20^{\circ} \mathrm{C}$ is enough to release fluid during cooking. The size of sarcomeres may result in loss of water due to the extra-myofibrillar spaces and subsequently extracellular areas. Honikel and others (1986) suggested that decreases in sarcomere length during rigor processes in excised bovine muscle could result in loss of water. Our results indicated that rainbow trout fillets, rich in fat, are susceptible to cook loss and denaturation of protein with minimal influence of time of postharvest processing on these heat-induced changes. 


\section{Fillet shortening (\%)}

Fillet shortening after slaughter is related to filleting time (Table 5). Sixteen percent shortening was observed $3 \mathrm{~h}$ after processing for fillets generated at $0 \mathrm{~h}$ postharvest. Only 3 percent shortening was observed for fillets generated from trout $24 \mathrm{~h}$ postharvest. Greater shortening for $0 \mathrm{~h}$ postharvestproduced fillets' is attributed to rigor contraction in the absence of skeletal restraint. This observation is in agreement with Sorensen and others (1997); Einen and others (2002). In addition, Venugopal (2006) also stated that fillets produced pre-rigor could contract freely and eventually shorten in length due to onset of rigor. This fillet shortening is also evidenced by shorter sarcomeres observed at $0 \mathrm{~h}$ postharvest (Figure 3). Skjervold and others (2002) reported that $0 \mathrm{~h}$ postharvest filleting reduced fillet length by $8.6 \%$ Morkore and others (2004) observed contraction immediately after filleting $0 \mathrm{~h}$ postharvest farmed cod stored at $0^{\circ} \mathrm{C}$ noting a $20 \%$ length reduction. Huss (1995) reported that fillet yield of fish in-rigor is usually poor. Meanwhile, shrinkage of $0 \mathrm{~h}$ postharvest rainbow trout fillets appears to be more extensive compared to $0 \mathrm{~h}$ postharvest-produced fillets of Atlantic salmon that showed 15\% length reduction (Sorensen and others 1997). Karl and others (1997) suggested that $0 \mathrm{~h}$ postharvest filleted cod are shortened as a result of chilled storage on ice.

\section{Myotome Length}

Myotomes (flakes) are parallel muscle fibers arranged in blocks, which are separated by sheets of connective tissue linking one myotome to the other; it contains collagen and lipid (Zhou and others 1995). Although small, there was an incremental increase in myotome length as postharvest processing time increased ( $\mathrm{P} \leq 0.05$; Table 5).

\section{Body Temperature}

Fish body temperature is a significant factor affecting onset and duration of rigor mortis. 
Temperature, as a function of time on ice, dropped from 7 to $4^{\circ} \mathrm{C}(\mathrm{P} \leq 0.05)$ during rigor processes

(Table 5). The 0 h postharvest fillets had a mean value of $7^{\circ} \mathrm{C}$, and temperature declined to 5 and $4{ }^{\circ} \mathrm{C}$ at 24 and $48 \mathrm{~h}$, respectively. Carcass temperature at $0 \mathrm{~h}$ was higher because fish had not been chilled, and $7^{\circ} \mathrm{C}$ is reflective of the water temperature.

\section{Sarcomere Length}

The sarcomere is the basic functional and structural unit of a muscle. To clarify the mechanism involved in tenderness and contractile state as a function of processing time, sarcomere length was examined as one of the ultrastructural changes. Sarcomere length of the rainbow trout fillets changed $(\mathrm{P} \leq 0.05)$ after processing and subsequent storage (Figure 3$)$. Shorter sarcomeres were observed at $0 \mathrm{~h}$ postharvest $(1.71 \mu \mathrm{m})$ compared to $24 \mathrm{~h}$ postharvest $(1.90 \mu \mathrm{m})$. Sigurgisladottir and others (2001) found that sarcomere length in raw fish muscle at early processing times is between 1.5 and $2.2 \mu \mathrm{m}$. Also, Shindo and others (1986) reported a sarcomere length of $1.7 \mu \mathrm{m}$ in rainbow trout muscle. It is likely that the shorter length observed for 0 -h processed fillets in the present study is due to rigor contraction in the absence of skeletal restraint.

\section{Dimensional Changes in Cooked Fillets}

Cooking raw muscle had a greater effect on dimensional changes than did time of processing, postharvest (Table 6). Sample dimensions were measured after cooking; at this point, processing time did not affect $(\mathrm{P}>0.05)$ the length, width, or thickness of the cooked samples. Although, the difference between raw and cooked sample increased $(\mathrm{P} \leq 0.05)$ as processing time increased. Considering that cooked moisture content decreased with processing time, it is plausible that dimensional changes were associated with greater dehydration of the 24- and 48-h than the 0-h processed fish. These data are consistent with increasing cooked fillet firmness. 


\section{Texture Analysis}

Allo-Kramer (AK) and variable blade (VB) shear force (Figure 4), and Allo-Kramer and variable blade energy (Figure 5; area under the curve), were measured to assess texture. Postharvest texture was dependent on storage and processing time $(\mathrm{P} \leq 0.05)$. Kramer shear force at 0 and $24 \mathrm{~h}$ postharvest was lower than at $48 \mathrm{~h}$ postharvest; additionally, variable blade shear force was higher at 24 and $48 \mathrm{~h}$ postharvest than at $0 \mathrm{~h}$ processing. This result agrees with the results of Sigholt and others (1997); Berg and others (1997); Skjervold and others (2001) in that extensive changes occurred in the fillets' texture (hardness) measured as shear force within the first $24 \mathrm{~h}$ postharvest. According to Feargemang and others (1995), fillet texture of farmed salmon is affected by storage time on ice. Variation in texture that develops for cooked fish products is attributable to muscle $\mathrm{pH}$, sarcomere length, water and fat content, and postmortem autolysis (Haard 1992). A softer texture in $0 \mathrm{~h}$ postharvest fillets could have been due to a higher $\mathrm{pH}$ and dissociated actin and myosin because fillets are in the pre-rigor stage. These results were supported by Dunajski (1979) who reviewed physical properties of muscle and indicated that sarcomeres are extensible and tissue is softer immediately after death while ATP concentration remains constant in preventing the association of actin and myosin.

Several studies have shown that degradation of fiber to fiber attachments (cytoskeleton) is linked to texture changes. Taylor and others (2006) observed that tenderness in the first $24 \mathrm{~h}$ of processing is associated with degradation of fiber to fiber attachment in muscle. On the contrary, Ando and others (1993) reported toughness in yellowtail (Seriola quinqueradiata) tissue immediately after death and rapid decreases firmness after $24 \mathrm{~h}$ of storage at $5^{\circ} \mathrm{C}$. Ando and others (1991) reported that breaking strength of rainbow trout fillets was high immediately after death and decreased between 12$24 \mathrm{~h}$ with gradual decreases continuing with longer storage. Differences in texture due to processing 
time may be associated with the progression of postmortem metabolism during rigor development.

Rigor mortis has a significant effect on texture (Howgate 1977), and this response is particularly affected by the storage environment. The work of Goll and others (1964); Calkins and Seideman (1988); Birkhold and Sams (1993); Wheeler and Koohmaraie (1994) established a relationship between rigor development and tenderness in terrestrial species. Toyohara and Shimizu (1988); Oka and others (1990) indicated that tenderization of fish muscle starts before the initiation of rigor. Ando and others (1993) concluded that softening of red sea beam tissue immediately after death is a result of the weakening of the pericellular connective tissue. Whereas, Hatae and others (1986) suggested that the contribution of connective tissue to texture in cooked fish is minimal. According to Offer and Knight (1988); Foegeding and others (1996); Dransfield (1996), cooking temperatures above $80^{\circ} \mathrm{C}$, in the presence of sufficient water, will convert collagen to gelatin, softening cooked meat texture; a much lower temperature would accomplish the same thing in trout muscle. As rigor mortis proceeds, ATP concentration decreases and lactic acid accumulates during glycolysis resulting in the decrease in $\mathrm{pH}$, which eventually affects the activity of proteases. Love (1983) reported that cod was soft and very tender when the $\mathrm{pH}$ was above 7 with high water content. It appears that a high $\mathrm{pH}$ in fish fillets correspond to greater softness (tenderness) while low $\mathrm{pH}$ is compatible with firmer (tougher) fillets. Similar results were observed in this present research work. In this particular study, there is a relationship between shear force, $\mathrm{pH}$, cooked moisture and fat content, and \% cook loss and fillet texture. Cooked moisture was higher, fat content was lower, muscle $\mathrm{pH}$ was slightly higher, and shear values were lower at $0 \mathrm{~h}$ processing time. These data suggest that fillet texture is influenced by moisture content. Dunajski (1979) reported that high lipid or moisture content could result in softer fillets. Research observed that fillets from rainbow trout Faergemand and others (1995); sea bream 
Orban and others (1997) fed high fat diets were higher in fat content. Sheehan and others (1996) observed that Atlantic salmon fillet softness is caused by an increase in fat content in the diet. Shenouda (1980) reported that loss of fluid and a change in texture was a result of denaturation and aggregation of the myofibrillar proteins (actomyosin).

Sarcomere length influences tenderness (Fennema 1996; Hatae and other 1990), and previous research has shown that sarcomere length increased with processing and storage time (Cavitt and others 2004). It is observed that the shorter the sarcomere length the tougher the texture of the muscle. The present study showed that sarcomere length was inversely related to fish muscle tenderness. The difference in shear force at $0 \mathrm{~h}$ processing time (48 h storage), compared to 24 and $48 \mathrm{~h}$ processing times, is high because of ATP depletion, additionally the associated $\mathrm{pH}$ decline contributes to an increase in fish fillet firmness and it is also likely associated with a shorter sarcomere length. Love (1956); Connell (1964), and found that degradation of fish muscle protein is connected with an increases in toughness, and Connell (1962) suggested that changes in muscle protein during storage decreases water holding capacity. $\quad$ Energy required to shear the sample, using Allo-Kramer, was significantly higher at $0 \mathrm{~h}$ processing time than at $24 \mathrm{~h}$ postharvest, and this may, in part, be due to differences in sarcomere length and a higher $\mathrm{pH}$. Toughness in fish, increased cook loss, and low moisture content with storage time may be, in part, due to increased bonding between myofibrillar proteins that result in cross-linking of the protein network and a reduction in the ability of the protein network to hold water (Connell 1964). Softer texture observed at $0 \mathrm{~h}$ postharvest may be associated with the higher $\mathrm{pH}$ for these samples and the activity of the calpain system; calpain activity is optimal at a neutral pH. Although, Ducastaing and others (1985); Vidalenc and others (1983) suggested that normal postmortem storage had little effect on the activity of calpain in red meat species. Based on 
data from both attachments, Allo-Kramer was more effective in separating differences in energy required to shear than the Variable blade attachment due to Allo-Kramer also assessing differences in compressive forces.

\section{Changes In ATP and Its Degradative Products}

ATP and its catabolites were measured at $48 \mathrm{~h}$ postharvest, and the catabolizes of ATP metabolism were not affected $(\mathrm{P}>0.05$ ) by time of processing (Figure 6). Although, trout muscle had a significantly $(\mathrm{P} \leq 0.05)$ higher concentration of ATP $(0.19 \pm 0.02)$ at $0 \mathrm{~h}$ postharvest than at $24 \mathrm{~h}$ postharvest $(0.13 \pm 0.02)$; 0 - and 48 -h values $(0.14 \pm 0.02)$ were not different. Azam and others (1989); Proctor and McLoughlin (1992); Berg and others (1997); Roth and others (2002) showed that slaughtering methods affect the rate of chemical reaction in the myotomal muscle postmortem. IMP is an important contributor to flavor (pleasant flavor) (Erikson and others1997). Following $48 \mathrm{~h}$ of refrigerated storage, the IMP content of the $0 \mathrm{~h}$ processing treatment was $1.18 \mu \mathrm{m} / \mathrm{g}$. Woyewoda and others (1986) observed that decreases in IMP result in loss of freshness and flavor. As nucleotide degradation continues, Hypoxanthine (Hx) and Inosine (INO) (off flavor) decrease, and they are suspected to cause a bitter flavor in stored fish (Foegeding and others1996). As with other catabolites, Hx was not affected $(\mathrm{P}>0.05)$. Hx concentration found in this study is similar to the report of Boyle and others (1991) for stored rainbow trout, and pacific cod (Green and Bernattbyrne 1990). Accumulation of Hx is indicative of the initial phase of autolysis. Jahns and others (1976) reported that Hx is a good indicator of fish freshness. Thomas and others (1999) reported that, in rainbow trout, inosine concentration was not affected by storage. Ozogul and others (2002) concluded that increases in IMP are compatible with pleasant flavor, which is acceptable for freshness. 


\section{K-value}

K-value, an indicator of fish freshness, is defined as the ratio of the sum of INO and Hx to the total of all ATP breakdown products (Ryder and others 1993; Vazquez-Ortiz and others 1997). Levels of adenine nucleotides and their related compounds differ according to differences in processing and storage time (Uchiyama and others 1970). K-value increased with time of processing postharvest from 58\% (0 h postharvest) to 62 and $61 \%$ (24 and $48 \mathrm{~h}$ postharvest, respectively) (Figure 7). K-value of 0h postharvest fillets was significantly different from 24 and 48 h postharvest fillet, K-value. Ehira and Uchiyama (1987) proposed that a K-value lower than 25\% is highly fresh; a K-value lower than 60\% is moderately fresh, and a $\mathrm{K}$-value greater than $70 \%$ is not fresh. Using this scale, rainbow trout processed at $0 \mathrm{~h}$ will be considered moderately fresher through $48 \mathrm{~h}$ of refrigerated storage. Be reminded that K-value for all processing treatments was determined on fillets at $48 \mathrm{~h}$ postharvest. Fish processed at $24 \mathrm{~h}$ postharvest and stored for 1 day, and fish processed at $48 \mathrm{~h}$ postharvest without storage were not fresh; albeit, these treatments resulted in fillets slightly less fresh than fillets processed at $0 \mathrm{~h}$ postharvest, according to K-value categories. Based on K-value, fillets in this study will be acceptable after 2days of storage at $4^{\circ} \mathrm{C}(0 \mathrm{~h}$ postharvest).

\section{ATP/IMP Ratio}

ATP/IMP ratio is an indicator of muscle metabolic activity. ATP/IMP ratio, following $48 \mathrm{~h}$ of storage, was significantly higher for 0-h processed fish than for 24- and 48-h processed fish (Figure 8). High ATP/IMP is indicative of a shift in cellular energy potential. ATP/IMP ratio showed the same trend as $\mathrm{pH}$, which is reasonable. The high $\mathrm{pH}$ at the $0 \mathrm{~h}$ postharvest (48 $\mathrm{h}$ storage) may be explained by the presence of ATP before significant accumulation of lactic acid. The decline in $\mathrm{pH}$, with concurrent glycogen breakdown, and depletion of ATP results in the formation of IMP. The ATP/IMP 
ratio trend in this study is similar to the result of Korhonen and others (1990) who found that ATP/IMP ratio in tilapia is about 1.17, 0.95, and 0.92 for pre-, full-, and post-rigor samples, respectively. Iwamato and others (1987) showed that the ATP/IMP ratio ranged from 0.1 to 0.5 in Plaice (Paralichthys olivaceus). Evaluation of fillet quality may be based on ATP breakdown during rigor development and resolution; ATP/IMP ratio is indicative of the energy state of the muscle following harvest and during storage. 


\section{Summary and Conclusion}

Muscle is a dynamic tissue that reacts fast to environmental conditions either positively or negatively thus affecting the quality of the meat. To maximize freshness; processing must be done as soon as possible after harvest. Processing fish at $0 \mathrm{~h}$ postharvest has positive effects on fillet appearance.

The content of ATP and its metabolites and K-value were used to assess freshness. Onset and progression of rigor in rainbow trout fillets is affected by the rate of ATP depletion and accumulation of IMP. The $0-\mathrm{h}$ processing treatment resulted in the lowest $\mathrm{K}$ value with this response measured following $48 \mathrm{~h}$ of storage; this finding suggests an improvement in freshness when fish are processed at 0 hour. Allo-Kramer and Variable-blade texture evaluation showed significant effects of processing and storage time on texture of rainbow trout fillets. Fillets from fish processed at 0 -h postharvest had higher $(\mathrm{P} \leq 0.05)$ shear force than those filleted 24 and 48 h postharvest. Sarcomere length was shorter at $0 \mathrm{~h}$ postharvest and greatest at $48 \mathrm{~h}$ postharvest. Sarcomere length appeared to be positively related to shear force in this study. A higher $\mathrm{pH}$ may have resulted in more protein degradation associated with calpain (neutral proteases) activity. Additionally, the higher $\mathrm{pH}$ may have affected the balance of protein-protein, protein-water, and protein-lipid interactions achieved following cooking of these fillets. It is my opinion that the importance of $\mathrm{pH}$ to muscle food quality cannot be overstated.

Based on shear force value and nucleotide degradation, early processing of rainbow trout will yield the highest quality fillets. 
Results from the present thesis have contributed to our knowledge of the impact of processing time, postharvest, on rainbow trout quality. Further studies are required to obtain a greater depth of understanding of the underlying mechanisms and the complex basis of factors affecting rainbow trout quality, and the interaction among these various factors. 


\section{References}

Abe H, Okuma E, 1991. Rigor-mortis progress of carp acclimated to different water temperatures. Nippon Suisan Gakkaishi. 57:2095-2100.

Ando S, Mori Y, Nakamura K, Sugawara A. 1993. Characteristic of lipid accumulation types in five species of fish. Nippon Suisan Gakkaishi. 59:1559-1564.

Ando M, Toyohara H, Shimizu Y, Sakaguchi M. 1991. Post-mortem tenderization of rainbow trout muscle caused by gradual disintegration of the extracellular matrix structure. J. Sci. Food Agric. 57(6):1165-1169.

AOAC. Official methods of analysis. $15^{\text {th }}$ ed. Washington DC: Association of Official Analytical Chemists. 1990.

Aussanasuwannakul A, Kenney PB, Brannan RG, Slider SD, Salem M, Yoa J. 2010. Relating Instrumental Texture, Determined by Variable-Blade and Allo-Kramer Shear Attachments, to Sensory Analysis of Rainbow Trout, Oncorhynchus mykiss, Fillets. J. of Food Sci. Vol. 75 (7):S365-S374.

Azam K, Mackie IM, Smith J. 1989. The effect of slaughter method on the quality of rainbow trout Salmo salar. during ice storage. Int. J. Food Sci. Technol. 24: 69-79.

Bendall JR. 1951. The shortening of rabbit muscles during rigor mortis: its relation to the breakdown of adenosine triphosphate and creatine phosphate and to muscular contraction. J. Physiol. 114:71-88.

Benson CC. 1928. “Hydrogen Ion Concentration of Fish Muscle”. Journal of Biological chemistry 78: 583-590.

Berg T, Erikson U, Nordtvedt TS. 1997. Rigor mortis assessment of Atlantic salmon (Salmon salar) and effects of stress. J. Food Sci. 62:439-446.

Birkhold SG, Sams AR. 1993. Fragmentation, tenderness and post-mortem metabolism of early harvested broiler breast fillets from carcasses treated with electrical stimulation and muscle tensioning. Poult. Sci. 72:577-582.

Bito M, Yamada K, Mikumo Y, Amano K. 1983. Studies on rigor mortis in fish. Differences in the mode of rigor mortis among some varieties of fish by modifies cutting's method. Bull Tokai Reg Fish Res Lab 109:89-96. 
Bligh EG, Shaw SJ, \& Woyewoda AD. 1988. The effects of drying and smoking on lipids of fish. In: Fish Smoking and Drying (edited by J.R. Burt). Pp. 41-52. London: Elsevier Applied Science Publications Ltd.

Borderias AG, Lamua M, Tejada M. 1983. Texture analysis of fish fillets and minced fish by both sensory and instrumental methods. J. Food Technol. 18:85-95.

Bosworth BG, Small BC, Mischke CC. 2004. Effects of transport water temperature, aerator type, and oxygen level on channel catfish Ictalurus punctatus fillet quality. J. World Aquac. Soc. 35: 410-417.

Boyle JL, Lisday RC, Stuiber DA. 1991. Adenine nucleotide degradation in modified atmosphere chill-stored fresh fish. J. Food Sci. 56: 1267.

Calkins CR, Seideman SC. 1988. Relationships among calcium-dependent protease, cathepsins B and $\mathrm{H}$, meat tenderness and the response of muscle to aging. J. Anim. Sci. 66:1186-1193

Candela M, Astiasaran I, Bello J. 1997. Effect of frying and warmholding on fatty acids and cholesterol of sole (Solea solea), codfish (Gadus morrhua) and hake (Merluccius merliccius). Food Chemistry. 58: 227-231.

Cavitt LC, Youm GW, Meullenet JF, Owens CM, Xiong R. 2004. Prediction of poultry meat tenderness using razor blade shear, Allo-Kramer shear, and sarcomere length. J. Food Sci. 69: SNQ11- 15.

Connell JJ. 1964. Fish muscle proteins and some effects on the processing, in proteins and their Reaction, Schuitz, HW, and Anglemier AF, Eds, Avi, Westport, Conn, 255.

Connell JJ. 1962. Changes in amount of myosin extractable from cod flesh during storage at $-14^{\circ} \mathrm{C}$. $\mathrm{J}$ Sci. Food Agric. 13: 607.

Cross HR, West RL, Dutson TR. 1981. Comparison of methods for measuring sarcomere length in beef semitendinosus muscle. Meat Sci. 5:261-266.

Curran CA, Poulter RG, Brueeton A, Jones NSD. 1986. Cold shock reactions in iced tropical fish. J. Food Technology, Vol. 21: 289-299.

de Francesco M, Parisi G, Medale F, Lupi P, Kaushik SJ, Poli BM. 2004. Effect of long-term feeding with a plant protein mixture based diet on growth and body/fillet quality traits of large rainbow trout (Oncorhynchus mykiss). Aquaculture 236: 413-429.

Dransfield E. 1996. Calpains from thaw rigor muscle. Meat Science. 43:311-320. 
Ducastaing A., Valin, C., Schollmeyer, J., and Cross, R. 1985. Effects of electrical stimulation of postmortem changes in the activities of two Ca dependent neutral proteases and their inhibitor in beef muscle. Meat Sci. 15:193-202.

Dunajski E. 1979. Texture of fish muscle. J. Texture Studies 10: 301-318.

Duran A, Erdemli U, Karakaya M, Yilmaz MT. 2008. Effects of slaughter methods on physical, biochemical and microbiological quality of rainbow trout Oncorhynchus mykiss and mirror carp Cyprinus carpio filleted in pre-, in- or post-rigor periods. Fisheries Science 74:11461156.

Ehira S, Uchiyama H. 1987. Determination of fish freshness using the K value and comments on some other biochemical change in relation to freshness. In: Kramer DE, Liston J, editors. Seafood Quality Determination. Elsevier. New York: p185-207.

Einen O, Guerin T, Fjaera SO, Skjervold PO. 2002. Freezing of pre-rigor fillets of Atlantic salmon. Aquaculture 212:129-140.

Elvevoll EO, Sorensen NK, Osterud B, Ofstad R, Martinez I. 1996. Processing of marine foods. Meat Science 43:265-275.

Erikson U. 2001. Rigor measurements In: Kestin SC, Warris PD, editors. Farmed fish quality. Cornwall, UK: Blackwell publishing. p 283-295.

Erikson U. and Misimi E. 2008. Atlantic salmon skin and fillet color changes effected by perimortem handling stress, rigor mortis, and ice storage. J. Food Science Vol. 73: Nr. 2.

Erikson U, Sigholt T, Seland A. 1997. Handling stress and water quality during live transportation and slaughter of Atlantic salmon (Salmon salar). Aquaculture 149: 234-254.

Ewart JC. 1887. “On Rigor mortis in Fish, and its Relation to Putrefaction”. Proceedings of the Royal Society of London 42: 438-459.

Exler J. 1987. Composition of Foods: Finfish and Shellfish Products. Washington DC: United States Department of Agriculture, Human Nutrition Service Agriculture Handbook. Pp. 8-15.

Faergemand J, Ronsholdt B, Alsted N, Borresen T. 1995. Fillet texture of rainbow trout as affected by feeding strategy, slaughtering procedure and storage post mortem. Water Sci Technol 31: 225231.

FAO. 2001. Cold storage of frozen fish. FAO in partnership with support unit for International Fisheries and Aquatic Research. [Electronic version]. Available from: http://www.fao.org.

FAO 2010. Fish Stat fishery statistical collections: aquaculture production (1950-2008; released March 2010). Rome, Italy: Food and Agriculture Organization of the United Nations. http://www.fao.org/fishery/statistics/ software/fishstat/en. 
Fennema OR. 1996. Food chemistry. 3rd edition. New York: Marcel Dekker. p 880-938.

Foegeding EA, Allen CE, Dayton WR. 1986. Effects of heating rate on thermally formed myosin, fibrinogen and albumin gels. J. Food Sci. 51: 104-108, 112.

Gokoglu N, Yerlikaya P, Cengiz E. 2004. Effects of cooking methods on the proximate composition and mineral contents of rainbow trout (Onchorhynchus mykiss). Food Chemistry. 84: 19-22.

Gomez-guillen MC, Montero P, Hurrado O, Borderias AJ. 2000. Biological characteristics affect the quality of farmed Atlantic salmon and smoked muscle. J Food Sci 65(1): 53-60.

Goll DE, Henderson DW, Kline EA. 1964. Postmortem changes in physical and chemical properties of bovine muscle. J. Food Sci 29:590-596.

Greene DH, Bernat-Byrne EI. 1990. Adenosine triphosphate catabolites as flavor compounds and freshness indicators in Pacific cod Gadus macrocephalus and Pollock Theragra chalcogramma. J. Food Sci 55:257-258.

Haard NF. 1992. Technological aspects of extending promotional quality of seafood. A review. J Aqua Food Prod Technol 1:9- 27.

Hamm D. 1981. Unconventional meat harvesting. Poult. Sci. 60 (Suppl. 1):1666. (Abstr.)

Hatae K, Tobimatsu A, Takeyama M, Matsumoto J. 1986. Contribution of the connective tissue on the texture difference of various fish species. Bull. J Soc Sci Fish 52: 2001-2007.

Hatae K, Yoshimatsu F, Matsumoto JJ. 1990. Role of muscle fibers in contributing firmness of cooked fish. J Food Sci 55: 693-696.

Honikel KO, Kim CJ, Hamm R, \& Roncales P. 1986. Sarcomere shortening of pre-rigor muscles and its influence on drip loss. Meat Science. 16: 267-277.

Howgate P. 1979. Fish. In: Food Microscopy (ed. by J.G. Vaughan). Pp. 343-389. Academic Press, London.

Huff-Lonergan E, Lonergan SM. 2005. Mechanisms of water-holding capacity of meat: The role of postmortem biochemical and structural changes. Meat Sci. 71(1): 194-204.

Huss HH, 1995. Quality and quality changes in fresh fish. FAO Fish. Tech. Paper 348. Rome, Italy.

Iwamoto M, Yamanka H., Watabe S, Hashimoto K. 1987. Effects of storage temperature on rigormortis and ATP degradation in plaice Paralichthys olif́aceus. muscle. J Food Sci 52: 15141517.

Jahns FD, Howe JL, Coduri RJR and AG. 1976. Food Technol. 30:27. 
Jobling M. 1994. Fish Bioenergetics. Chapman and Hall, London.

Karl H, Muenkner W, Oehlenschlaeger J. 1997. Influence of ice and frozen storage thawing on the length of marine fish fillets. Inf. Fischwirtsch. 44 (1): 38-41.

Koolmees PA, Korteknie F, Smulders FJM. 1986. Accuracy and utility of sarcomere length assessment by laser diffraction. Food Microstructure. 5:71-76.

Korhonen RW, Lanier TC, Geibrecht F. 1990. An evaluation of simple methods for following rigor development in fish. J. Food Sci 55:346-368.

Kristoffersen S, Tobiasen T, Esaiassen M, Oisson GB, Godvik LA, Seppola M.A, Oisen RL. 2006. Effects of pre-rigor filleting on quality aspects of Atlantic cod (Gadus morhua L.). Aquaculture Res 37:1556-15564.

Lauritzsen K, Akse L, Johansen A, Joensen S, Sorensen NK, Olsen RL. 2004. Physical and quality attributes of salted cod (Gadus morhua L.) as affected by the state of rigor and freezing prior to salting. Food Research International 37:677- 688.

Little AC, Martinsen C, Sceurman L. 1979. Color assessment of experimentally pigmented rainbow trout color. Res. Appl 4: 92-95.

Loughna PT, Goldspink G. 1985. Muscle protein synthesis rates during temperature acclimation in a eurythermal (Cyprinus carpio) and a stenothermal (Salmo gairdneri) species of teleost. Journal of Experimental Biology 118: 267-276.

Love RM. 1956. Influence of Freezing-rate on the denaturation of cold-stored fish. nature. 178: 988 989.

Love RM. 1983. Texture and the fragility of fish muscle cells. Research at the Torry Research Station. Review paper. J. Texture Studies 14: 323-352.

Love RM, Lavety J, and Garcia NG. 1972. The connective tissue of fish VI. Mechanical studies on isolated myocomata. J. Food Technology 7: 291-301.

Love RM, 1988. Food fishes- their intrinsic variation and practical implication London, UK: Farrand Press. p. 179-180.

Lowe T, Ryder JM, Carrager JF, Wells RMG. 1993. Flesh quality in snapper, Pagrus auratus, affected by capture stress. J. Food Sci 58: 770-773,796.

Morkore T, Hansen SJ, Rorvik KA. 2004. Product quality of farmed cod. Contraction of pre-rigor fillets in relation to storage temperature (in Norwegian). Program Conference Aquaculture, 2324. March, Clarion Hotell Oslo Airport, Gardermoen, Norway. 
Morkore T, Rorvik KA. 2001. Seasonal variation in quality characteristics within and between age classes of farmed Atlantic salmon (Samo salar). In: Kestin SC, Warris PD. Farmed fish quality. Fishing new books. Oxford UK: Blackwell science. p 388.

Mørkøre T, Hansen AA, Unander E, Einen O. 2002. Composition, liquid holding capacity and mechanical properties of farmed rainbow trout: variation between fillet sections and the impact of ice and frozen storage. J. Food Sci. 67:1933-1938.

Offer G, Knight P. 1988. The structural basis of water-holding in meat. Part 1. General principles and water uptake in meat processing. In: Developments in Meat Science New York (NY): Elsevier Applied Science Publishing Co. Inc. 4: 63-171.

Ofstad R, Kidman S, Myklebust R. \& Hermansson AM. 1993. Liquid-holding capacity and structural changes during heating of fish muscle: cod (Gadus morhua L.) and Salmon (Salmo salar). Food Structure12:163-174.

Oka H, Ohno K, Ninomiya J. 1990. Changes in texture during cold storage of cultured yellowtail meat prepared by different killing method. Bull Jpn SOC Sci Fish. 56 (10): 1673-1678.

Orban E, Sinesio F. and Paoletti F. 1997. The functional properties of the proteins, texture and the sensory characteristics of frozen sea bream fillets (Sparus aurata) from different farming systems. Food Sci Technol 30:214-217.

Ozbay G, Spencer K, Gill TA. 2006. Investigation of protein denaturation and pigment fading in farmed steelhead (Onchorhynchus mykiss) fillets during frozen storage. J Food Process Preserv 30:208-30.

Ozogul Y, Ozogul F, 2004. Effects of slaughtering methods on sensory, chemical and microbiological quality of rainbow trout (Onchorynchus mykiss) stored in ice and MAP. European Food Research and Technology 219: 211-216.

Ozogul F, Taylor KDA, Quantick P, Ozogul Y. 2002. Biogenic amines formation in Atlantic herring (Clupea harengus) stored under modified atmosphere packaging using a rapid HPLC method. International Journal of Food Science and Technology. 37:515-522.

Poli BM, Parisi G, Zampacavallo G, Scappini P, de Francesco M. 2003. The effect of slaughter methods on European sea bass (Dicentrarchus labrax) behaviour, rigor onset, plasmatic and tissue stress indexes and quality. Proceedings of the "First Joint Trans-Atlantic Fisheries Technology Conference (TAFT)”. 33rd and 48th Atlantic Fisheries Technology Conference. 11-14 June 2003, Reykjavik, Iceland.

Proctor MRM, McLoughlin JV. 1992. The effects of anesthesia and electrical stunning on chemical changes in the myotomal muscle of Salmo salar post mortem. Proc. Royal Irish Acad. 92B: 5359. 
Robb DHF, Kestin SC. 2002. Methods used to kill fish: field observations and literature reviewed. Animal Welfare: 11:269-282.

Robb DHF, Kestin SC \& Warriss PD. 2000. Muscle activity at slaughter: I. Changes in flesh color and gaping in rainbow trout. Aquaculture. 182: 261-269.

Roth B, Moller D, Veland JO, Imsland A, and Slinde E. 2002.The effect of stunning methods on rigor mortis and texture properties of Atlantic salmon (Salmo salar). J. Food Science 67:1462-1466.

Roth B, Slinde E, Arildsen J. 2006. Pre or post mortem muscle activity in Atlantic salmon (Salmo salar). The effect on rigor mortis and the physical properties of flesh Aquaculture. 257: p 504510.

Ryder JM, Fletcher GC, Stec MG, and Selye RJ. 1993. Sensory, microbiological and chemical changes in hoki stored in ice. Int Food Sci Technol 28:169-180.

Sato K, Ohashi C, Ohtsuki K, Kawabata M. 1991. Type V collage in trout (Salmo gardineri) muscle and its solubility change during chilled storage of muscle. J Agric Food Chem. 39:1222 -1225.

Sellevold OF, Jynge P, Aarstad K. 1986. High performance liquid chromatography: a rapid isocratic method for determination of creatine compounds and adenine nucleotides in myocardial tissue. J. Mol. Cell Cardiol. 18(5):517-527.

Semmens K. 2010. Aquaculture situation and outlook report University of Maryland, 2113 Animal Science Building, College Park, Maryland.

Sen DP. 2005. Advances in Fish Processing Technology. Allied Publ. Pvt. Ltd., New Delhi.

Sheehan EM, O’ Conner TP, Sheehy PJA, Buckley DJ, and FitzGerald R. 1996. Effects of dietary fat intake on the quality of raw and smoked salmon. Irish Journal of Agricultural and Food Research 35: 37-42.

Shenouda SKY. 1980. Theories of protein denaturation during frozen storage of fish flesh. In: Advances in Food Research. Chichester C, Mark E, Stewart G, editors. New York: Academic Press. p 275-311.

Shindo K, Tsuchiya T, and Matsumoto JJ. 1986. Histological study on white and dark muscles of various ${ }^{\circledR}$ shes. Bulletin of the Japanese Society of Science Fish 52: 1377-1399.

Sigurgisladottir S, Sigurdardottir MS, Ingvarsdottir H, Torrissen OJ, and Hafsteinsson H. (2001). Microstructure and texture of fresh and smoked Atlantic salmon, Salmo salar L., fillets from fish reared and slaughtered under different conditions. Aquaculture Research. 32:1-10.

Sigholt T, Erikson U, Rustad T, Johansen S, Nordtvedt TS, Seland A. 1997. Handling stress and storage temperature affects meat quality of farmed-raised Atlantic salmon Salmo salar. J. Food Sci. 62 (4): 898-905. 
Sikorski ZE, Kolakowska A, and Burt JR. 1990. Postharvest biochemical and microbial changes. Ch. 4. In:. Sikorski ZE , editors. Seafood Resources, Nutritional Composition, and Preservation. Inc. Boca Raton FL : CRC Press. 55-75.

Skjervold PO, Fjaera SO, Ostby PB. 1999. Rigor in Atlantic salmon as affected by crowding stress prior to chilling before slaughter. Aquaculture 175: 93-101.

Skjervold PO, Fjæra SO, Ostby PB, \& Einen O. 2001. Live chilling and crowding stress before slaughter of Atlantic salmon (Salmo salar). Aquaculture 192: 265-280.

Skjervold PO, Fjaera SO, Ostby PB, Isaksson T, Einen O, Taylor R. 2002. Properties of salmon flesh from different locations on pre- and post-rigor fillets. Aquaculture 201: 91-106.

Skjervold PO, Rora MB, Fjaera SO, Vegusdal A, Vorre A, Einen O. 2001a. Effects of pre-in-, or post-rigor filleting of live chilled Atlnatic salmon. Aquaculture 194:315-326.

Skjervold PO, Fjaera, SO, Ostby PB, Isaksson T, Einen O, Taylor R. 2001b. Properties of salmon flesh from different locations on pre- and post-rigor fillets. Aquaculture 201:91-106.

Skrede G, Storebakken T. 1986. Instrumental color analysis of farmed and wild Atlantic salmon when raw, baked and smoked. Aquaculture 53:279-286.

Sorensen NK, Brataas R, Nyvold TE, Lauritzen K. 1997. Influence of early proceeding (pre-rigor) on fish quality. In: Luten J. B. Borresen T, Oehlenschlaeger, J. Editors Seafoods from producer to consumer, integrated approach to quality. Amsterdam: Elsevier. p 253-263.

Stien LH, Hirmas E, Bjornevik M, Karisen O, Nortvedt R, Rora, AMB, Sunde J, Kiessling A. 2005. The effects of stress and storage temperature on the color and texture of pre-rigorfilletred cod (Gadus morhua IL.) Aquaculture Res 36:1197-1206.

Taylor RG, Geesink GH, Thompson VF, Koohmaraie M, Goll DE. 1995. Is Z-disk degradation responsible for postmortem tenderization? J Anim Sci 73:1351-1367.

Thomas PM, Pankhurst NW, and Bremner HA. 1999. The effect of stress and exercise on post mortem biochemistry of Altantic salmon and rainbow trout. J fish biology. 54:1177-1196.

Tokur B. (2000). The quality changes of trout (Onchorhynchus mykiss, W. 1792) fillets with vegetable sauce during frozen storage. PhD Thesis, Ege Univ. Natural Sci. Ins. p 161.

Tokur B. (2007). The effect of different cooking methods on proximate composition and lipid quality of rainbow trout (Oncorhynchus mykiss). International J. Food Science and Technology. 42:874-879.

Toyohara H, and Shimizu Y. 1988. Relation of the rigor mortis of the fifh body and the texture of the muscle. Nippon Sulsan Gakkaishi 54:1795-1798. 
Uchiyama H, Ehira S, Kawahara T, Shimidu W. 1970. Significance in measuring volatile base and trimethylamine nitrogen and nucleotides in fish muscle as indices of freshness. Bull. Jpn. Soc. Sci. Fish. 36:177-181.

Urbieta F, Ginés R. 2000. Optimisation of slaughtering method in gilthead sea bream (Sparus aurata). Industrial application in fish farms. Cahiers Options Méditerranées 51: 71-77.

Vázquez-Ortiz F, Pacheco-Aguilar R, Lugo-Sánchez M, Villegas-Ozuna R. 1997. Application of the freshness quality index (K value) for fresh fish to canned sardines from northwestern Mexico. Journal of Food Composition and Analysis. 10:158-165.

Venugopal V. 2006. Seafood processing: adding value through quick freezing, retortable packaging, cook chilling and other methods. Taylor and Francis group, USA CRC press.

Vidalenc, P., Cottin, P., Merdaci, N., and Ducastaing, A. 1983. Stability of two Ca2+-dependent neutral proteinases and their specific inhibitor during postmortem storage of rabbit skeletal muscle. J Sci Food Agric. 34: 1241- 1245.

Wall AJ. 2001. Ethical considerations in the handling and slaughter of farmed fish. In: Kestin SC, Warriss PD. editors. Farmed Fish Quality. Fishing News Books. Oxford: p 108-115.

Watabe S, Hwang GC, Hashimoto K. 1990. Changes in rigor-mortis progress of carp induced by temperature acclimation. Agric Biol Chem 54: 219-221

Wheeler TL, Koohmaraie M. 1994. Pre-rigor and post-rigor changes in tenderness of Ovine longissimus muscle. J Anim Sci 72:1232-1238.

Wills CC, Zampacavallo G, Poli BM, Proctor MRM, Henehan GTM. 2006. Nitrogen stunning of rainbow trout. International J. Food Sci. \& Techn, 41(4): p 395-398.

Woyewoda AD, Bligh EG. 1986. Effect of phosphate blends on stability of cod fillets in frozen storage. J Food Sci 5: 932-935.

Yanar Y, Celik M. and Akmaca E. 2006. Effect of brine concentration on shelf life of smoked tilapia (O. niloticus) stored at $4^{\circ} \mathrm{C}$. Food Chem. 97: 244-247.

Zhou S, Ackman RG, \& Morrison C. 1995. Storage of lipids in the myosepta of Atlantic salmon Salmo salar. Fish Physiology and Biochemistry. 14:171-178. 


\section{Tables and Figures}

Table 1: Biological characteristics of rainbow trout (Oncorhynchus mykiss) fillets processed at different postharvest periods.

\begin{tabular}{|l|l|l|l|l|}
\hline \multicolumn{5}{|c|}{ Treatments (Time Postharvest) } \\
\hline Responses & $0 \mathrm{~h}$ & $24 \mathrm{~h}$ & $48 \mathrm{~h}$ & $\mathrm{SE}$ \\
\hline Condition factor & 1.2 & 1.2 & 1.2 & 0.03 \\
\hline Length (cm) & 42.3 & 40.9 & 41.7 & 0.52 \\
\hline Whole body weight (g) & 929.6 & 840.1 & 871.7 & 38.84 \\
\hline $\begin{array}{l}\text { Head on gutted weight } \\
\text { (g) }\end{array}$ & 813.2 & 735.3 & 761.8 & 30.38 \\
\hline $\begin{array}{l}\text { Head on gutted weight } \\
\text { (\%) }\end{array}$ & 87.5 & 87.7 & 87.5 & 0.91 \\
\hline $\begin{array}{l}\text { Butterfly weight yield } \\
(\%)\end{array}$ & 66.6 & 66.9 & 66.5 & 0.64 \\
\hline $\begin{array}{l}\text { Separable muscle (\%) } \\
\text { Belly fat }\end{array}$ & 46.9 & 47.9 & 47.7 & 0.49 \\
\hline
\end{tabular}

SE-Standard Error, h- Hour 


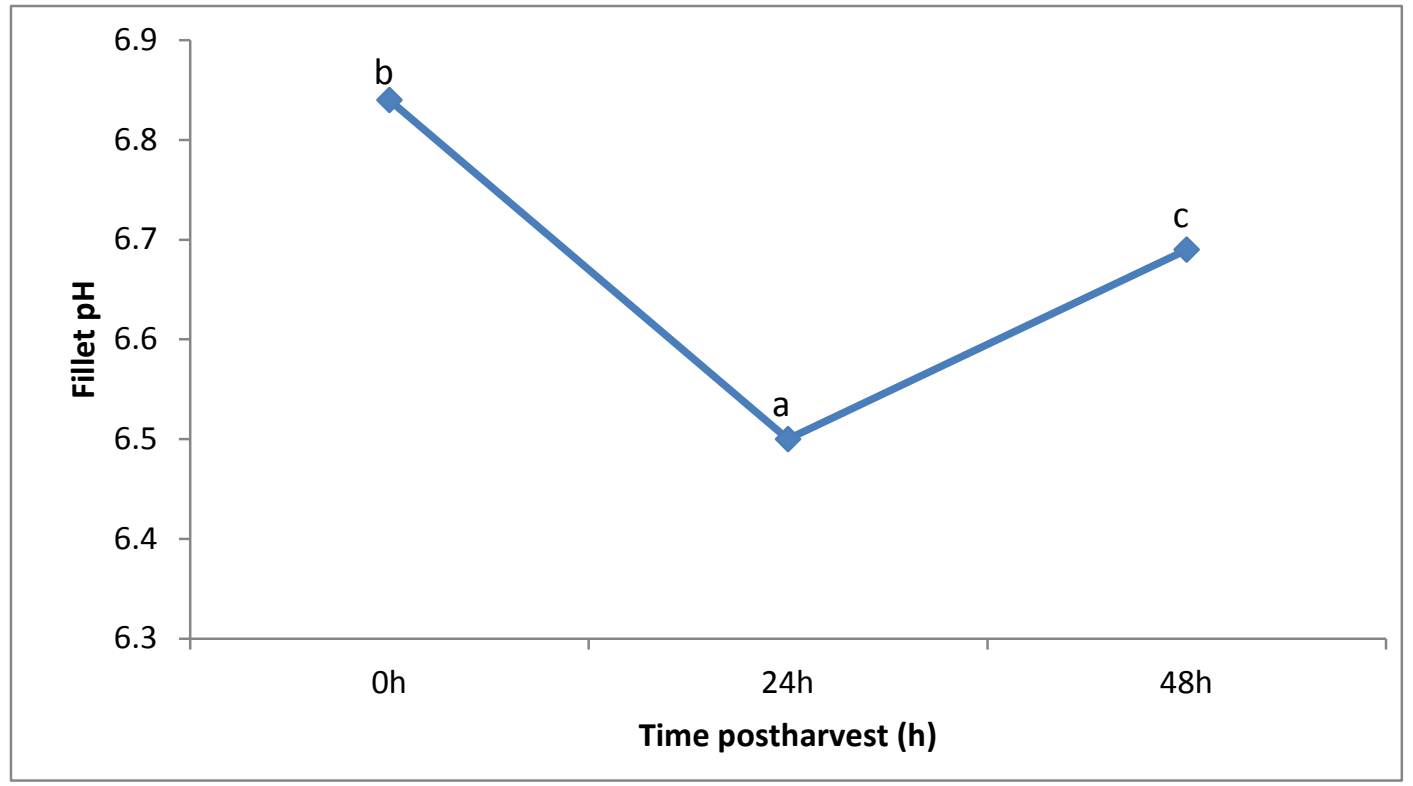

Figure 1: Muscle $\mathrm{pH}$ of rainbow trout filleted at 0,24 and $48 \mathrm{~h}$ postharvest. Values with different letters are different $(\mathrm{P} \leq 0.05)$. 


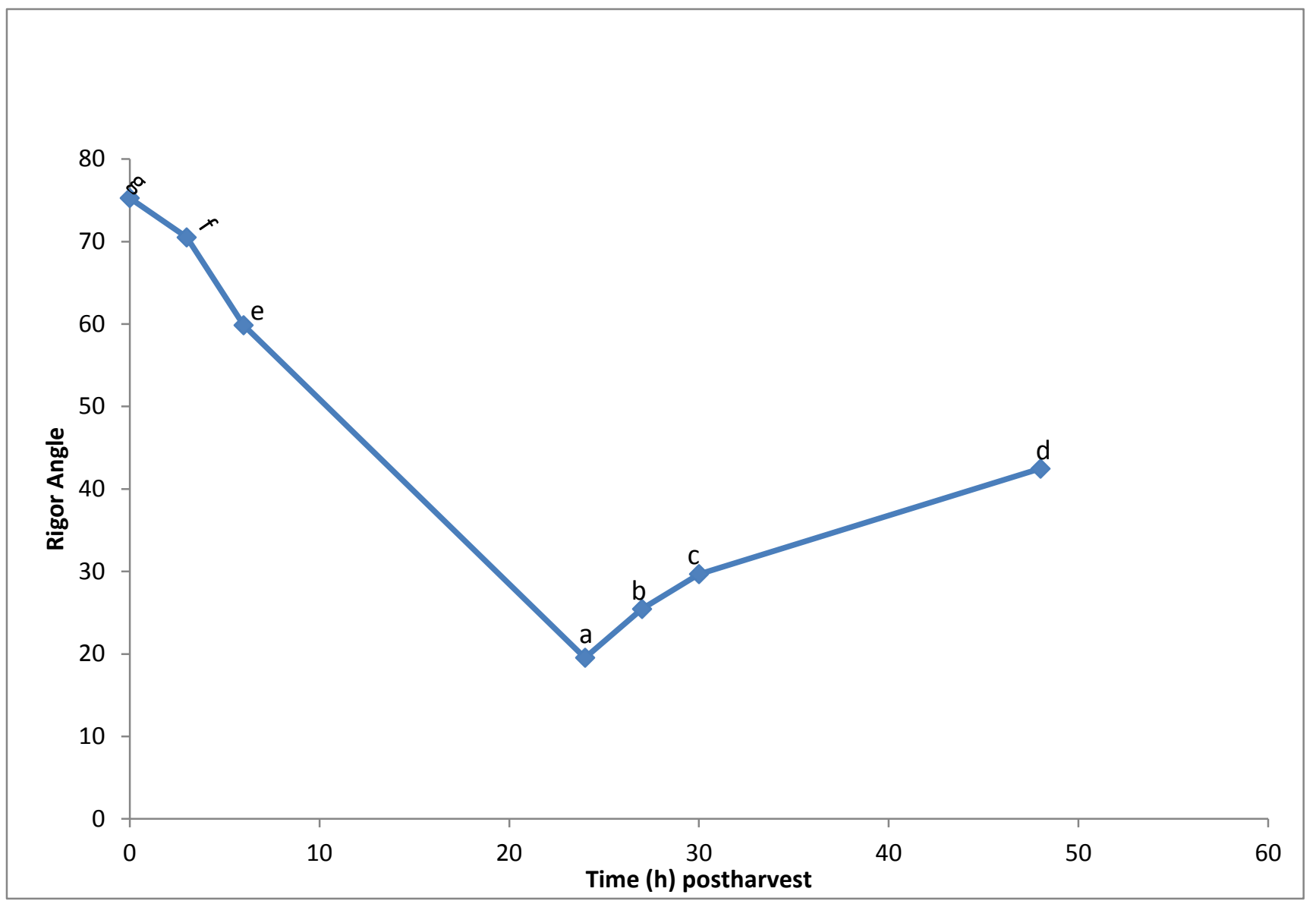

Figure 2: Effect of time postmortem on rigor development. The rigor angle was measured at 0 , $3,6,24,27,30$, and 48 hours postharvest. Values with different letters are different $(\mathrm{P} \leq 0.05)$. $\mathrm{h}=$ Hour 
Table 2: Average fillet color $\left(L^{*}, a^{*}\right.$, and $\left.b^{*}\right)$ of rainbow trout processed at different postharvest periods: $0 \mathrm{~h}$ postharvest, $24 \mathrm{~h}$ postharvest and $48 \mathrm{~h}$ postharvest.

\begin{tabular}{|l|l|l|l|l|}
\hline \multicolumn{5}{|c|}{ Treatments (Time postharvest) } \\
\hline Responses & $0 \mathrm{~h}$ & $24 \mathrm{~h}$ & $48 \mathrm{~h}$ & SE \\
\hline Lightness (L*) & $40.70^{\mathrm{ab}}$ & $39.36^{\mathrm{a}}$ & $42.11^{\mathrm{b}}$ & 0.52 \\
\hline Redness (a*) & $3.00^{\mathrm{b}}$ & $0.86^{\mathrm{a}}$ & $0.68^{\mathrm{a}}$ & 0.36 \\
\hline Yellowness (b*) & $7.16^{\mathrm{b}}$ & $4.43^{\mathrm{a}}$ & $4.03^{\mathrm{a}}$ & 0.36 \\
\hline
\end{tabular}

Means in the same row with different letters are different $(\mathrm{P} \leq 0.05)$. $\mathrm{h}=$ Hour, SE- Standard Error 
Table 3: Proximate composition of raw trout fillets at different time postharvest.

\begin{tabular}{|l|l|l|l|l|}
\hline \multicolumn{5}{|c|}{ Treatments } \\
\hline Responses & $0 \mathrm{~h}$ & $24 \mathrm{~h}$ & $48 \mathrm{~h}$ & SE \\
\hline Moisture \% & 72.90 & 73.44 & 73.71 & 0.35 \\
\hline Ash \% & $1.28^{\mathrm{b}}$ & $1.24^{\mathrm{b}}$ & $1.17^{\mathrm{a}}$ & 0.02 \\
\hline Fat \% & 6.43 & 6.81 & 6.31 & 0.39 \\
\hline Protein \% & $20.71^{\mathrm{b}}$ & $20.18^{\mathrm{a}}$ & $19.95^{\mathrm{a}}$ & 0.12 \\
\hline
\end{tabular}

Means in the same row with different letters are different $(\mathrm{P} \leq 0.05)$. SE-Standard Error, h- Hour

Table 4: Effects of processing times on proximate composition of cooked rainbow trout fillet.

\begin{tabular}{|l|l|l|l|l|}
\hline \multicolumn{5}{|c|}{ Treatments (Time postharvest) } \\
\hline Responses & $0 \mathrm{~h}$ & $24 \mathrm{~h}$ & $48 \mathrm{~h}$ & SE \\
\hline Cook Fat \% & 4.69 & 4.86 & 5.41 & 0.55 \\
\hline Cook Loss \% & 11.09 & 12.40 & 12.43 & 0.52 \\
\hline Cooked Moisture \% & $69.41^{\mathrm{b}}$ & $69.25^{\mathrm{ab}}$ & $68.49^{\mathrm{a}}$ & 0.36 \\
\hline
\end{tabular}

Means in the same row with different letters $(a, b)$ are different $(\mathrm{P} \leq 0.05) . \mathrm{h}=$ Hour, SE- Standard Error 
Table 5: Changes in shortening (\%), myotome, and body temperature in rainbow trout processed at different time after harvest.

\begin{tabular}{|c|c|c|c|c|}
\hline \multicolumn{4}{|c|}{ Treatments (Time postharvest) } & \\
\hline Responses & Oh & $24 \mathrm{~h}$ & $48 \mathrm{~h}$ & SE \\
\hline Fillet shortening (\%) & $16.08^{b}$ & $3.37^{\mathrm{a}}$ & & 1.36 \\
\hline Myotome (Mm) & $4.1^{\mathrm{a}}$ & $4.2^{\mathrm{a}}$ & $4.3^{\mathrm{b}}$ & 0.01 \\
\hline Body temperature $\left({ }^{\circ} \mathrm{C}\right)$ & $7^{c}$ & $5^{\mathrm{b}}$ & $4^{\mathrm{a}}$ & \\
\hline
\end{tabular}

Means in the same row with different letters $(\mathrm{a}, \mathrm{b})$ are different $(\mathrm{P} \leq 0.05)$. $\mathrm{h}=$ Hour. SE- Standard Error 


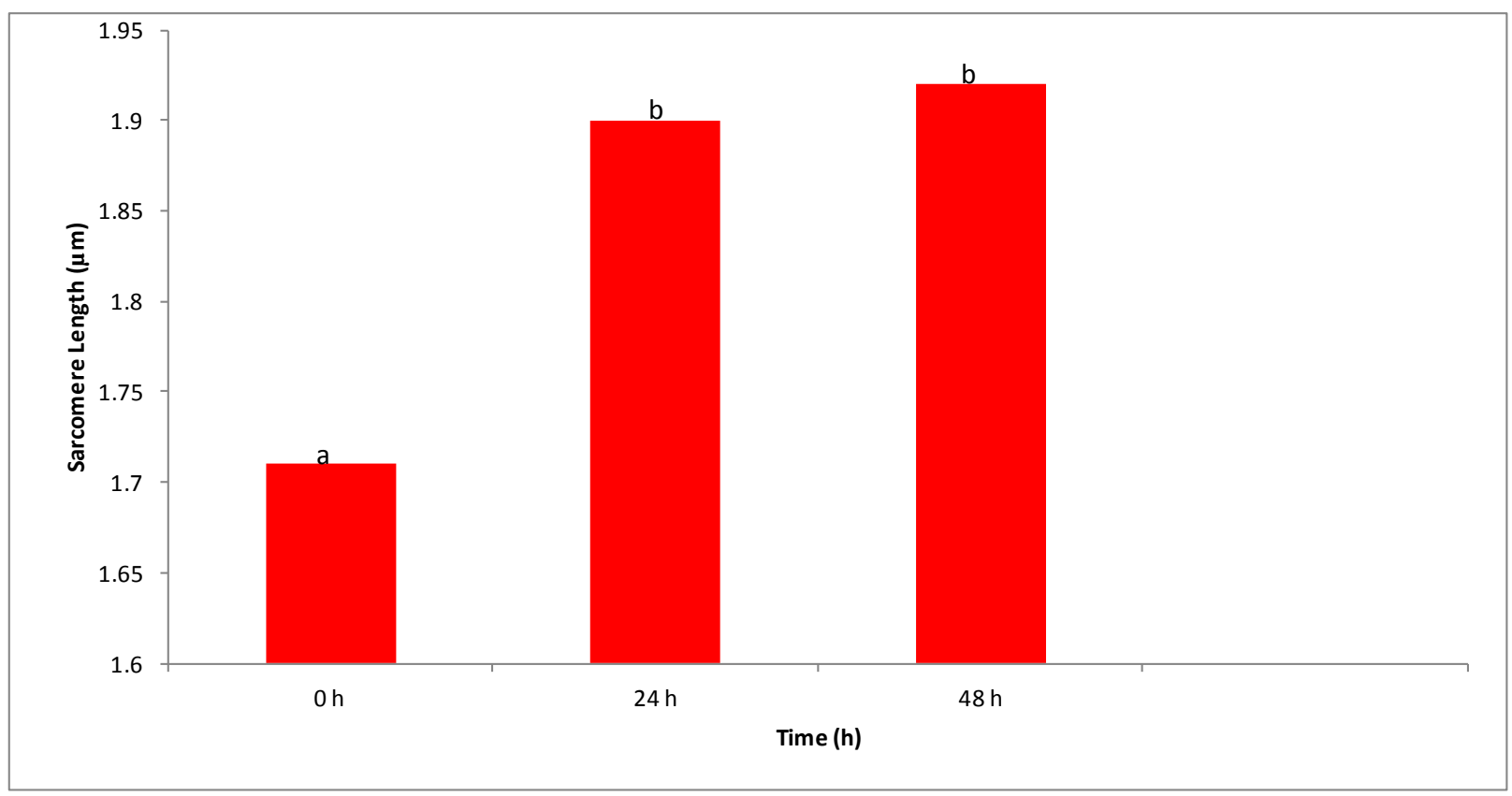

Figure 3:Sarcomere length of rainbow trout fillet processed at different postharvest periods. Means with different letters are different $(\mathrm{P} \leq 0.05)$. $\mathrm{h}=$ Hour, SE- Standard Error 
Table 6: Changes in length, width, maximum height, and area of cooked rainbow trout fillet at different processing and storage periods.

\begin{tabular}{|l|l|l|l|l|}
\hline \multicolumn{5}{|c|}{ Treatments (Time postharvest) } \\
\hline Responses & $0 \mathrm{~h}$ & $24 \mathrm{~h}$ & $48 \mathrm{~h}$ & SE \\
\hline Length change & 0.68 & 0.66 & 0.63 & 0.04 \\
\hline Width change & -0.16 & 0.03 & 0.04 & 0.04 \\
\hline Thickness & 0.02 & -0.01 & 0.03 & 0.02 \\
\hline Difference in r-c & $4.79^{\mathrm{a}}$ & $5.61^{\mathrm{b}}$ & $7.14^{\mathrm{b}}$ & 0.93 \\
\hline
\end{tabular}

At the end of $48 \mathrm{~h}$ postharvest storage, Means in the same row with different letters $(\mathrm{a}, \mathrm{b})$ are different $\quad(\mathrm{P} \leq$ 0.05). $\mathrm{r}-\mathrm{c}=$ raw-cook. SE- Standard error. $\mathrm{h}=$ Hour 


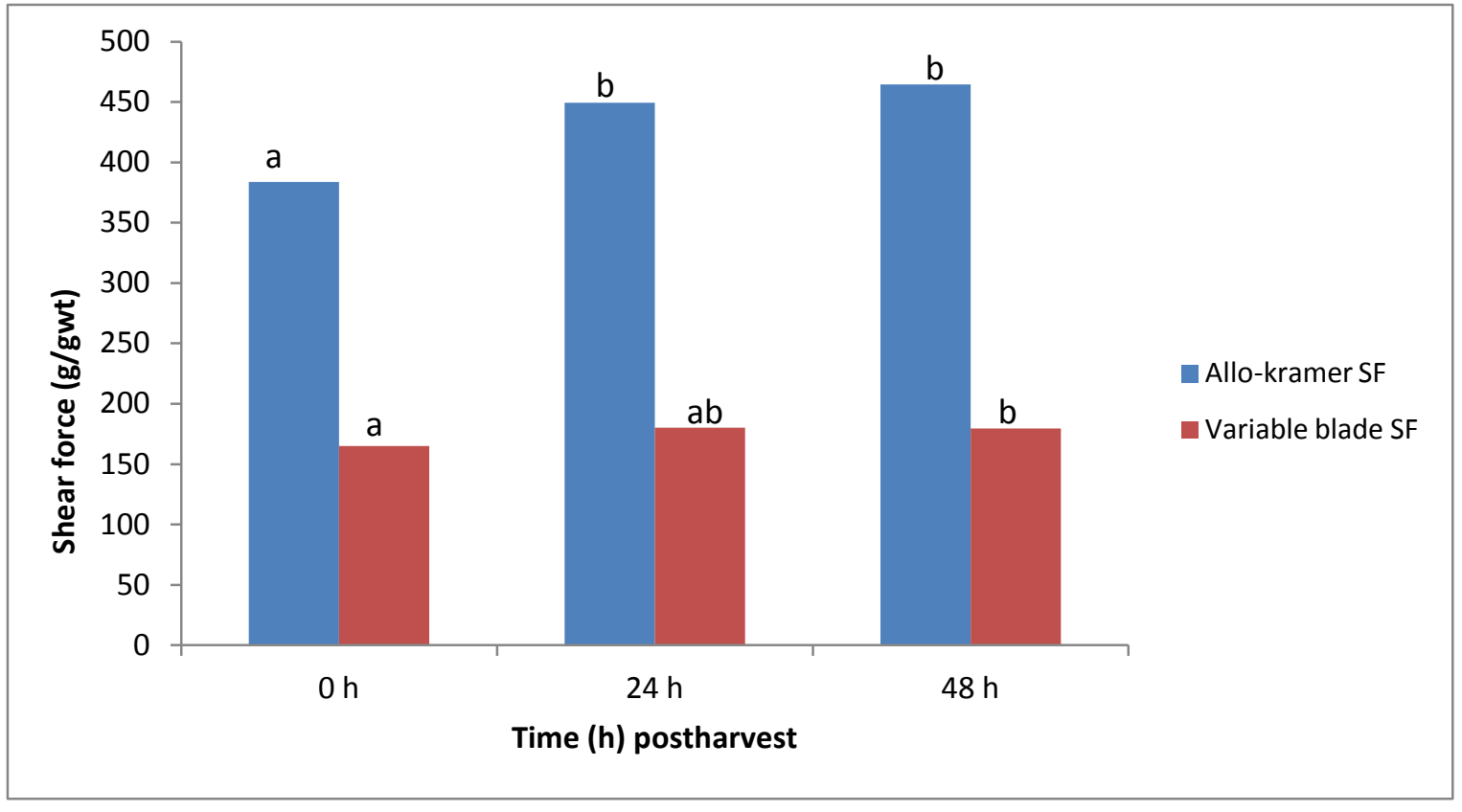

Figure 4: Allo-Kramer and Variable blade shear force of rainbow trout fillets processed at different postharvest periods. Means within each response with different letters are different $(\mathrm{P} \leq 0.05)$. $\mathrm{SF}=$ Shear force. $\mathrm{h}=$ Hour 


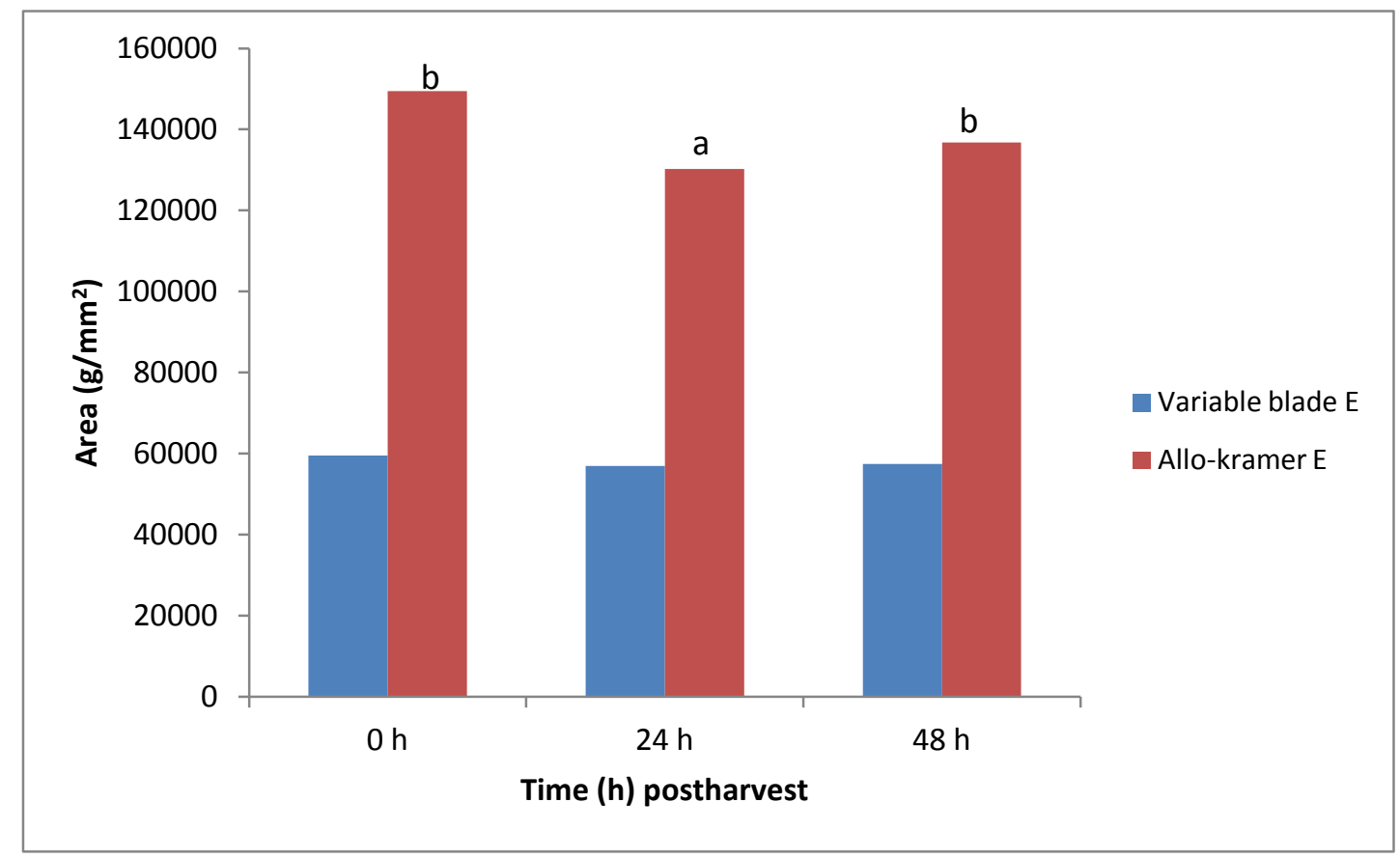

Figure 5: Allo-Kramer and Variable blade shear energyof rainbow trout fillet processed at different postharvest periods. Means within each response with different letters are different $(\mathrm{P} \leq 0.05)$. $\mathrm{E}=$ energy=area. 


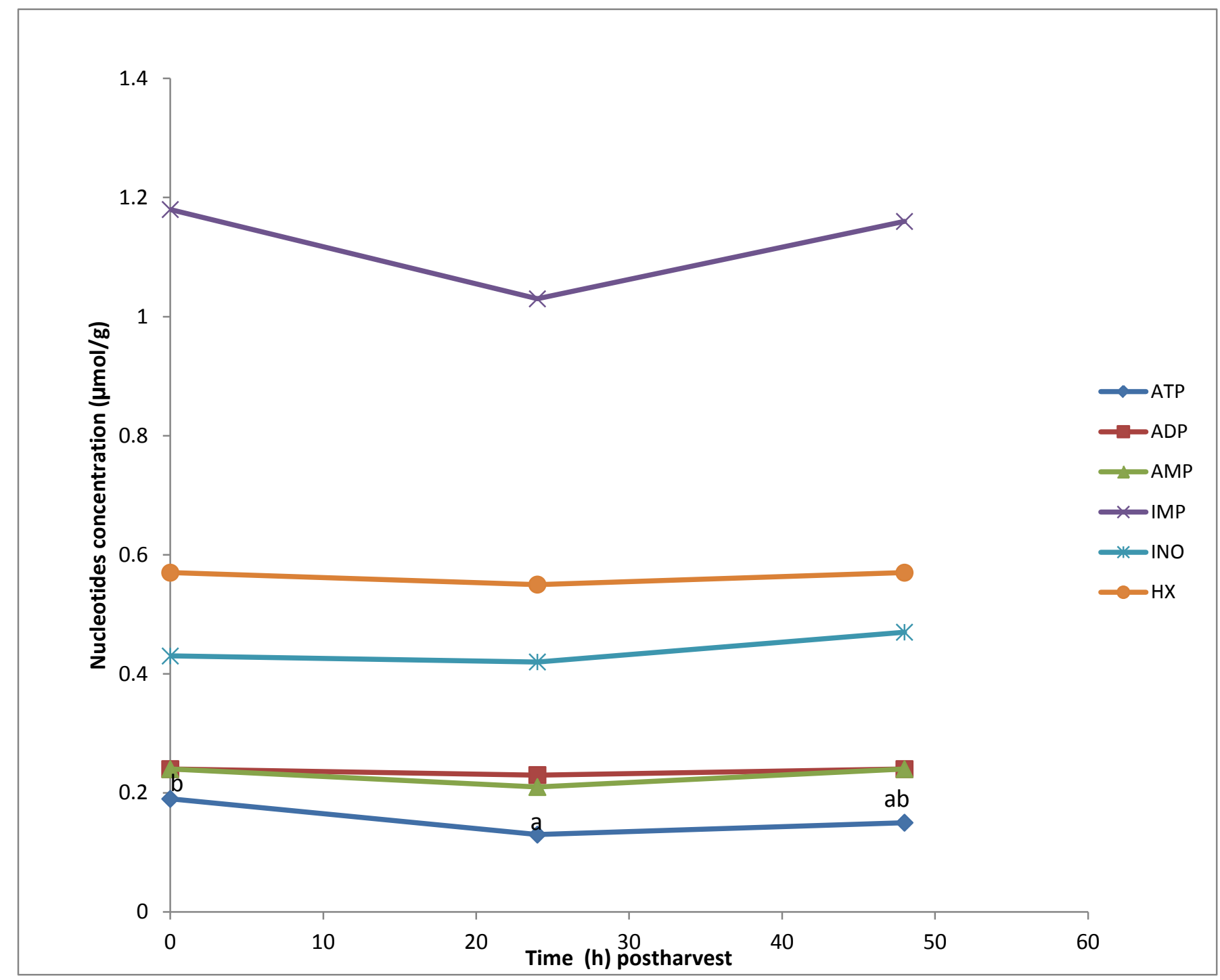

Figure 6: Changes in nucleotide content in muscle of rainbow trout processed at different postharvest periods. Each point is the mean of five filets. Means within each response with different letters are different $(\mathrm{P} \leq 0.05)$. ATP $=$ Adenosine triphosphate, $\mathrm{ADP}=$ Adenosine diphosphate, $\mathrm{AMP}=$ Adenosine monophosphate, $\mathrm{IMP}=$ inosine monophoshate, $\mathrm{INO}=$ inosine, and $\mathrm{HX}=$ Hypoxanthine. 


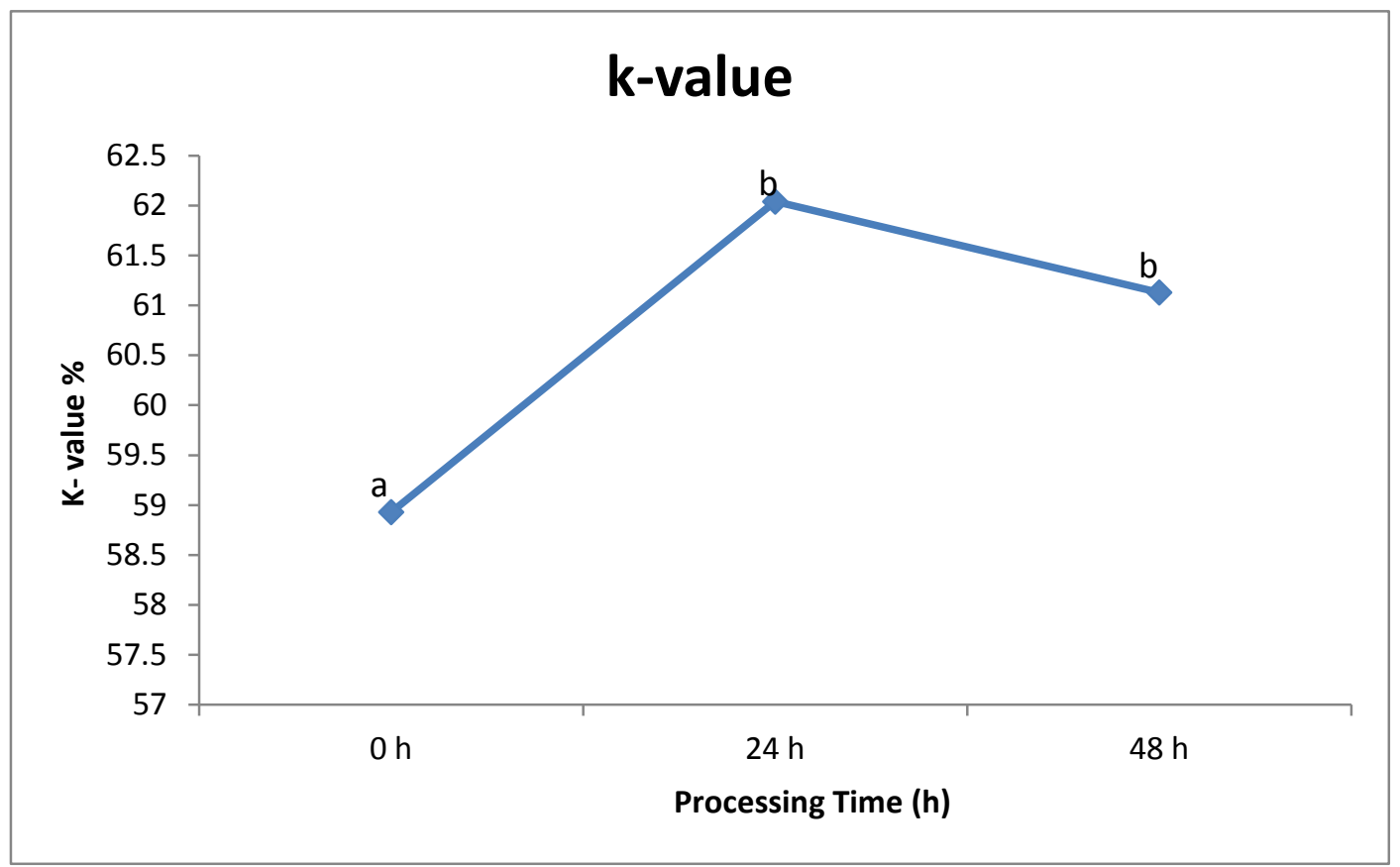

Figure 7: Changes in K-value of rainbow trout muscle processed at different postharvest periods. Each point is the mean of five filets. Means with different letters are different $(\mathrm{P} \leq 0.05)$. $\mathrm{h}=$ Hour 


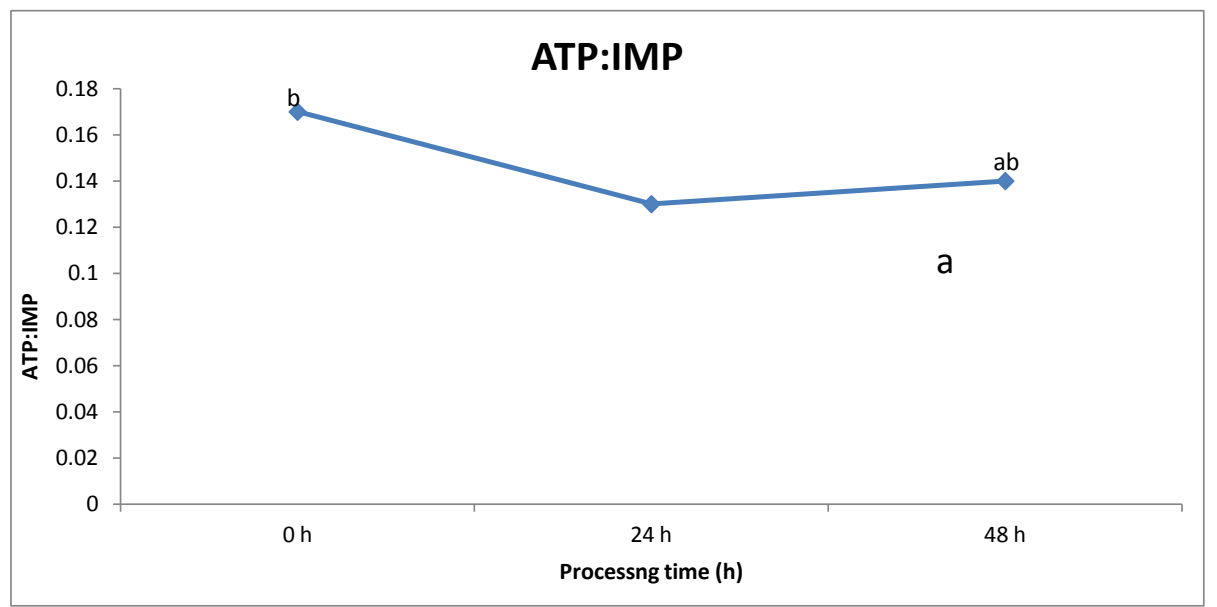

Figure 8: ATP: IMP ratio in muscle of rainbow trout processed at different postharvest periods. Each point is the mean of five filets. Means with different letters are different $(\mathrm{P} \leq 0.05)$. $\mathrm{ATP}=$ Adenosine triphosphate and IMP $=$ inosine monophoshate. $\mathrm{h}=$ Hour 


\section{Curriculum Vitae}

Parents: Joseph A. Ayeni

Omotunde E. Ayeni

Date of Birth: January 24, 1977

Schools Attended: Federal University of Technology,

Akure, Ondo State. Nigeria

Degrees Conferred: Bachelor of Agriculture, 2002

Master of Science in Animal and Nutritional Sciences, 2012 